\title{
TITLE: Indications and limitations of phage therapy in human medicine: Personal experience and literature review
}

\section{Authors}

Alain Dublanchet*, médecin-biologiste honoraire des Hôpitaux, ancien chef du laboratoire de microbiologie CHI Lucie et Raymond Aubrac, Villeneuve Saint Georges, 94190, France

Olivier Patey, médecin-infectiologue, chef de service, service des maladies infectieuses et tropicales, CHI Lucie et Raymond Aubrac, Villeneuve Saint Georges, 94190, France

Hubert Mazure, HGM Consultants, 63 Rebecca Parade, Winston Hills, NSW, 2153, Australia

Max Liddle, 63 Kangaroo Street, Manly, NSW, 2095, Australia

Anthony M. Smithyman, Cellabs Pty Ltd, and founder Special Phage Services, both of Brookvale, NSW, 2100, Australia

*Correspondence : Alain Dublanchet. 46 rue Céline Robert, 94300 Vincennes, France

E-mail : adublanchet@orange.fr Téléphone : 331603134340

\begin{abstract}
Bacteriophages, viruses that are widespread throughout the world, are highly specific for bacteria, usually of a single species and often of a particular strain. After being discovered and isolated 100 years ago, their use, called phage therapy, was instituted in medicine two years later and quickly used around the world to treat various bacterial infections. In the West, phage therapy was overshadowed in the second half of the 20th century by antibiotic therapy, which was then thought to be the definitive solution. But because of the increase in bacterial resistance to antibiotics, the idea of using bacteriophages in medicine has been reawakened. The innumerable observations reported over the years in the literature constitute an invaluable experience. We and some of our colleagues have, in the last decade treated some patients compassionately. With the available documentation and our own experience we discuss the potential indications and limitations of phage therapy. The observation of the increasing number of therapeutic failures in the announced perspective of a post-antibiotic era, we believe, that the introduction of bacteriophages into the therapeutic arsenal seems conceivable today to two preconditions: that their production as biologic drug meets current regulatory standards and that the benefit-risk assessment was conducted in a modern setting. Phage therapy could be applied as a substitution or supplement to antibiotic therapy under multiple circumstances in different modes, precise indications and limits.
\end{abstract}

Keywords: bacterial infection; antibiotic resistance; bacteriophage; antibiotic therapy; phage therapy; review

\section{1) Introduction}

In 1917, Félix d'Hérelle observed a phenomenon in stool cultures from convalescent patients with bacillary dysentery [1]. He asserted the corpuscular nature of clear zones that had appeared on the bacterial layers and made the assumption that these clear zones were caused by an "invisible microbe" capable of killing bacteria. He gave the name of bacteriophage to this "microbe". Two years later (1919), he demonstrated that the oral administration of bacteriophages in humans is harmless and causes the healing of bacterial enteritis caused by Shigella sp. (bacillary dysentery). This demonstration was reported in 1921 in a book summary [2] of about seven documented cases including five hospitalized and two outpatient cases. It was in 1922 that the first publication [3] of a series of localized staphylococcal infections (boils) treated by local injection of bacteriophages showed that infections with various bacteria could be successfully treated. From then on, based on a large number of cases, the interest of this new treatment in various infections quickly became clear. Gradually, until the discovery of antibiotics, their therapeutic application proved widely successful worldwide. But after the discovery of antibiotics, faced with easier use of antibiotics, the application of 
phage therapy was gradually abandoned in Western countries until it finally disappeared in France with the closure in the late 1990s of the only possible source of therapeutic bacteriophages still existing in two Pasteur institutes (Paris and Lyon).

In recent years, we have witnessed the worldwide spread of multidrug-resistant bacteria. As new and truly innovative antibiotics are rare and new classes are absent, the rising frequency of therapeutic failures are raising fears of a new pre-antibiotic era [4]. To respond to this worrying situation, the return of phage therapy seemed to be an answer not only alternative [5] but complementary [6] to faltering antibiotic therapy. In this perspective, a century of publications on this subject with series of bacterial infections treated by phage therapy as well as some recent cases, could constitute an invaluable source of knowledge. In this mass of knowledge, it would be unfortunate not to use the large body of information acquired over the years and published in French or Russian. Easily accessible, these results are accompanied by remarks and comments that are useful to help set up modern therapeutic protocols. This is what we propose to report here by adding our own experience of cases, particularly osteo-articular infections treated under compassionate protocols.

However, today, any substance, chemical or biological used for medical purposes, is considered a drug and this is the case for suspensions of bacteriophages. The preparation of a drug is governed by health regulations in particular in Europe ${ }^{1}$ and in the United States ${ }^{2}$. In this journal issue, a solution is proposed by Belgian colleagues [7]. To ensure quality, safety and efficacy, an evaluation of the benefit to risk ratio must then be made with an approach that is appropriate from an experimental and regulatory point of view $[8,9]$.

\section{2) Recent discoveries}

Since its discovery 100 years ago, the study of bacteriophages, predators of bacteria, has revealed that in addition to bacterial lysis, bacteriophages have other properties that should be taken into account in modern applications of phage therapy. Without pretending to be exhaustive, we point out some of them while indicating significant references about them. These "new facts" should be taken into account when preparing a modern bacteriophage suspension "tailored" to a patient [10-12] for personalised or individualised phage therapy.

\section{a) Exploration of synergies with antibiotics}

Although observed at the discovery of penicillin [13,14], the synergistic action between bacteriophages and antibiotics has been described for many antibiotics and for several bacterial species. Thus today the reintroduction of phage therapy is often proposed as a simple "alternative" to antibiotic therapy [15]. However, several recent studies both in vitro [16,17] and in vivo based on numerous experimental animal models have confirmed the interest of a joint use by showing the synergy of specific bacteriophage-antibiotic combinations at sometimes sub-inhibitory doses. The reintroduction of phage therapy deserves to be approached with the idea that it could be, not only an alternative, but also a complement in circumstances where the diffusion of an antibiotic is weak, for example in bone tissue or hampered by the presence of a biofilm [6]. For practical use the provision of a standard routine test would be necessary for a reasoned choice of the best combination by interference with self-inductors.

More recently, it has come to light that bacteria can communicate by releasing small mediating molecules, called self-inductors (Quorum Sensing), that allow bacteria to synchronize and adapt their behaviour by developing, among other things, a biofilm but also to protect themselves against the

\footnotetext{
${ }^{1}$ Defined by EU under Article 1(2) of Directive 2001/83, the definition of 'medicinal product' covers: « Any substance or combination of substances presented as having properties for treating or preventing disease in human beings: ...»" ${ }^{2}$ In the US, a "drug" is: «A substance recognized by an official pharmacopoeia or formulary... intended for use in the diagnosis, cure, mitigation, treatment, or prevention of disease. Biological products are included within this definition and are generally covered by the same laws and regulations, but differences exist regarding their manufacturing processes (chemical process versus biological process. »)
} 
attack of bacteriophages. For fifteen years, several mechanisms have shown to be able to block the genetic expression of self-inductors or to destroy their signals (Quorum Quenching). It has been proposed to use these mechanisms to prevent bacteria from communicating and thus to facilitate the action of bacteriophages as well as antibiotics [18].

\section{b) Blocking bacterial receptors}

It has been shown that bacteriophages, by attaching themselves to the bacterial surface at particular sites, could block resistance mechanisms such as an efflux pump [19], impair fitness or the virulence factor of a bacterium [20]. This would then make certain bacteria (eg Pseudomonas aeruginosa or Klebsiella pneumoniae) more susceptible to traditional antibiotics and facilitate the healing of certain pathologies such as endocarditis or vascular prosthesis infections [21]. Could these interactions be exploited to increase the effectiveness of phage therapy [22] by creating so-called "smart" cocktails [23] in the framework of a tailored phage therapy?

\section{c) Action against biofilms}

The major pathogenic role of biofilms appears fundamental in chronic infections, especially in the presence of foreign materials (prosthesis for example). The proteolytic enzymes of certain bacteriophages are capable of destroying polysaccharides in biofilms that allow bacteria to escape natural defences and antibiotic treatments [24]. In addition to allowing the adhesion of bacteriophages this action facilitates the diffusion of antibiotics. This activity should, as for synergy with antibiotics, benefit from a preliminary test.

It has been shown [25] that to combat Staphylococcus aureus infections, the therapeutic results can be influenced not only by the above properties but also by the sequence in which the therapeutic agents are administered. The best results are obtained when phage therapy precedes antibiotic therapy. As interesting as this effect may be one must not forget that it is necessary to confirm the best choice (of the bacteriophage (s) and of antibiotic (s)) by performing initial tests that are yet to be invented.

It should be noted that soluble degradation products of the components of $S$. aureus biofilms could have a deleterious role on osteoblasts [26] and thus limit the growth of bone callus. This would explain the rapid bone healing after use of bacteriophages.

\section{d) Adaptive coevolution with bacteria}

In nature, bacteriophages and bacteria maintain a close relationship in a permanent equilibrium with a succession of mutations that are a source of continual transformations. For example, if a bacterium modifies phage receptors on its surface, it becomes resistant to the bacteriophage. A bacteriophage, by the same process of mutation, is able to adapt to host resistances. Within microecosystems, the two protagonists are constantly changing in a coevolution. A recent review [27] of resistance mechanisms on both the bacterial and phage sides is of interest to us from the prudent perspective of using bacteriophages to prevent the bacterium from developing resistance during treatment [28]. On the contrary, the in vitro exploitation of this coevolution is at the root of the training phenomenon which exalts the virulence of the bacteriophage. This coevolutionary process, which has been known for a long time [29] and is highly recommended since the birth of phage therapy [30], has been rediscovered in recent years [31] and has been repeatedly mentioned by the first phage therapists [32]. It offers the practical application of enhancing the virulence and efficacy of a bacteriophage as a therapeutic agent against a pathogenic bacterium.

Thus, if a bacteriophage-resistant bacterium can be seen during a treatment, it is easy to rapidly obtain in vitro a variant bacteriophage effective against two bacterial clones. Two publications, respectively on Enterococcus faecalis [33] and Escherichia coli [34] have shown that the combination of clones of the two bacteriophages in a cocktail would produce a dual additive function ("guardkiller"). 


\section{e) Interactions with mammals (their cells and/or the host)}

Bacteriophages are traditionally considered to be biological agents that act as predators as soon as they encounter a host bacterium. Recently, it became apparent that other factors intervene.

\section{Impact of bacteriophages on the immune system}

Although still little explored, the relationship of bacteriophages with the immune system seems essential. Studies indicate that in addition to their well-known antibacterial action, bacteriophages have potent immunomodulatory properties. For some authors, the success of phage therapy depending on the bacterial permissiveness of the bacteriophage is related to the immunity of the subject. In particular, for Roach et al. [35] neutrophil-bacteriophage synergy is essential for the cure of pneumonia. For Dabrowska [36] the impact on the immune system affects the final outcome of phage therapy. While antibody induction may play a role in eliminating bacteriophages, it has also been shown that they can induce cytokine production in mammalian immune cells.

\section{Interaction with mammalian cells}

Adherence of bacteriophages to cells can define their pharmacokinetics and hence their efficacy in phage therapy by forming bacteriophage foci on tissues and organs [37]. Could this property be used to treat certain inflammatory diseases of the digestive tract [38]?

\section{f) Microbiomes}

Bacteriophages are present in all micro-ecosystems found in nature. The recent study of these systems has been made accessible thanks to the progress of new techniques of molecular biology, for which bacteriophages have been fundamental models. Recent key developments, including advances in bacteriophage genomics and microscopy, have sparked a renaissance in bacteriophage research over the last decade. The human microbiomes studied are either obvious (digestive tract, vaginal cavity, etc...) or less so (skin, urine [39], etc...). Today Precision Medicine, launched in January 2015, recommends a good knowledge of their existence [40]. The notion of microbiome must be borne in mind when a bacteriophage treatment is being considered [41]. Indeed, the introduction of a bacteriophage in a higher organism is not without consequence because it induces interactions difficult to predict which can facilitate or hinder the intended effect [42]. Indeed, there are interactions not only with the microbiome with which it comes in contact but possibly with eukaryotic tissue cells [38] and the immune system of the host organism [43]. Consequently, one can speak of "household with three in the bed" [44]. In particular, it is important to know that the intestinal microbiota of every individual is the host of the densest microbial community, which contains not only bacteria, archaea and fungi, but also mainly viruses, of which bacteriophages are the majority and largely unexplored [45]. A good knowledge of these could help improve treatment outcomes. These major biological entities that contribute to homeostasis are present, not only in our gut, but in all human microbiomes (skin [46], urine [47], various mucous membranes [48,49], etc ...). This should make phage therapy a personalized medicine [50] and use a very specific drug to treat a particular infectious event [51] as was done in the case presented in Box 1.

\section{Box 1: Creation in the United States of a centre dedicated to phage therapy}

Researchers at the University of California Medical School in San Diego have founded the first North American centre for innovative bacteriophage applications, the IPATH (Innovative Phage Applications and Therapeutics).

In 2016, physicians and scientists at the San Diego School of Medicine tried everything to save the life of Tom Patterson, a 69-year-old professor in the school's psychiatry department. While on vacation in the Middle East he had contracted a systemic infection with a multidrug-resistant bacterium (Acinetobacter baumannii). Luckily, Tom is married to Steffanie Strathdee, Associate Dean of Global Health Sciences, Harold Simon Professor, UCSD Department of Medicine. With help from colleagues, she obtained an emergency authorisation to treat her husband with bacteriophages after the failure of all standard antibiotic 
treatments. Experimental cocktails of bacteriophages were produced to effectively treat Tom Patterson intravenously. Patterson is the first American patient with a systemic multidrug-resistant bacterial infection successfully treated by phage therapy [50]. Subsequently, doctors at UC San Diego Health treated five other patients with bacteriophages for life-threatening bacterial infections.

Encouraged by the positive results seen in these early patients, a grant of $\$ 1.2$ million over three years was obtained to help launch the centre. Steffanie Strathdee, in collaboration with with Harold Simon and Robert Schooley, medical professors and infectious disease expert at the UC San Diego School of Medicine, will be the co-directors of IPATH.

For further information: https:/health.ucsd.edu/news/topics/phage-therapy/Pages/default.aspx

\section{3) Prerequisites for the medical use of bacteriophages}

The first condition is to have bacteriophages capable of being used for treatment. A larger number of different bacteriophages that are deposited in different collections target clinically relevant bacterial hosts. It would be desirable that the collections held in these "banks" organize themselves into a network to facilitate exchanges. If one needs a particular bacteriophage that is not available in such an organization, it is almost always possible to isolate one from the environment [52].

Therapeutic bacteriophages are biomedicines that must comply with the regulations that govern the production and evaluation of drugs. In addition, to deliver optimum treatment it is necessary to define its use in a dosage adapted to the location of the infection and the dosing rules (dose, rate and duration of treatment).

\section{a) Production}

The European Good Manufacturing Practices (GMP) guide guarantees the quality of a medicine [53]. This requires that a procedure be defined for their manufacture and for a combination of physicochemical and biological tests. The quality of a biological drug is harder to guarantee and control than that of a chemical. An adaptation of the regulation is necessary [9] which, in particular, will have to take into account the fact that such a drug can be a cocktail of several bacteriophages and probably to envisage its preparation within the framework of an individualized preparation [54] for a personalized medicine $[8,55]$. This personalized preparation may be sometimes necessary if the bacterial infection is unusual (opportunistic bacteria) and/or that no bacteriophages adapted have not yet been isolated (see Box 1) for a such bacteria. In personalized phage therapy, specific bacteriophages (sometimes called autophages [56] a preparation requiring a few days to a few weeks) are carefully selected from a collection (bacteriophage bank) or from the environment to treat a patient's specific bacterial infection [57]. According to various sources, the success rates of custom bacteriophage cocktails would be five to six times higher than those of standardized bacteriophages ([58], as cited by Sulakvelidze et al. [59]), which should favour the use of these "custom-made" cocktails in difficult cases, without excluding "ready-to-use" cocktails that in many cases will be sufficient. Only the common bacteria (Staphylococcus sp. and E. coli for example) would be treated with "ready-to-use" cocktails while the bacteria rarely encountered will require individual preparations. In any case, appropriate and safe procedures should be considered to prepare a bacteriophage suspension for use in humans (see Casey et al. [60]).

\section{b) Utilisation}

The administration of a drug is conditioned by the galenic forms and the vectorization that can be applied to it [61]. The liquid form (suspension) was generally proposed initially for phage therapy and widely used, most often locally. But all routes of administration were performed: oral, local, subcutaneous, parenteral (IV, IM), peritoneal, nebulized, etc ... Some precautions were highlighted including the sensitivity of bacteriophages to various physical parameters. chemicals like gastric 
acidity and some antiseptics. The products resulting from the preparation of the bacteriophages, in particular the bacterial endotoxin, could cause some undesirable reactions (fever, hepatitis, headache). Today it is easy to detect and eliminate these residues. Active research has developed on this topic in recent years [9].

\section{Galenic formulations}

The liquid form, specific or polyvalent (cocktail), continues to be most often used. But many other forms have been developed or are contemplated: tablets, powder [62], dressing, suppository, topical (cream and ointment) [63], etc ... Recently and notably, preparations have been developed for pulmonary administration $[64,65]$. They are used for infections of the upper or lower airways (lungs). In addition to acute pneumonia it would be especially useful for treating acute attacks of respiratory diseases with bacterial colonization. Case in point, cystic fibrosis [66] is a genetic disease that develops in children and leads to recurrent secondary infections requiring many antibiotics. Over time, resistant bacteria lead to complicated situations. As a substitute or supplement to antibiotic therapy, phage therapy adapted to infections appears as a promising way to treat episodes of infection flare up.

\section{Modes of administration}

The local application is the easiest to apply. Tolerance is good. Reactions (fever, local inflammation, hepatic pain), are moderate, rare and transient; they appear to be related to the endotoxins contained in the preparation or released by bacterial lysis. However, the release of endotoxins seems less of a problem than with antibiotics [67]. Bacteriophages being of protein nature, one is concerned with an anaphylactic reaction following repeated administration. However, severe reactions have always been the exception and today the risk is further reduced by the advanced purification methods available.

Diffusion is rapid and circulating bacteriophages are sequestered by the reticuloendothelial system in the spleen and liver. In the absence of bacterial target and host bacteria, bacteriophages are quickly eliminated. On the other hand, if bacterial targets are present, bacteriophages multiply in situ. Some people call them "smart" drugs.

\section{Dosage}

Dosage, rhythm and duration of treatment required have been poorly studied. Theoretically, insitu multiplication requires only one application. In practice, repetition is often the rule. Unlike conventional drug treatments, the pharmacological parameters are poorly defined at present, the main difficulty being to understand the in vivo multiplication.

\section{c) Validation and clinical studies}

Like any drug, a biomedicine must be studied experimentally to appreciate its positive and negative effects on a living organism. Numerous animal models specific to each type of pathology have been developed. For each model, a targeted study on the localization (skin, lung, bone, digestive tract, etc ...) and the bacteria (Staphylococcus sp., P. aeruginosa, enterobacteria, etc ...) allows to obtain reference data on the biology or the prognosis of an infection treated by one or more bacteriophages.

If such animal studies are numerous and clearly demonstrate efficacy, then human clinical trials need to be conducted in four successive phases to obtain the regulatory authorisation to commercialise a therapeutic preparation validated to GMP standards by the regulatory agency. Although innumerable publications (individual cases and clinical series) have shown positive results of phage therapy and presented few adverse effects, it is necessary to respond to modern requirements and to carry out randomized, double-blind controlled trials [68]. Nonetheless simpler, hospital observational studies, despite their drawbacks and inadequacies, would make it possible to envisage a response to pressing 
requirements while respecting the prerequisites (number of patients likely to be included within a defined period of time). So far there are many questions remaining unresolved, such as

- The need to repeat validation for each new preparation. With each new preparation will the experiments need to be repeated?

- Or, the revaluation of combination therapies, such as use with antibiotics and how the combined effect should be evaluated?

\section{4) Clinical indications cited in the literature}

A large number of human clinical cases for therapeutic treatment treated with phage therapy have been reported before the advent of antibiotics and even recently in the Eastern European countries (Russia, Poland, Romania, Georgia). Notwithstanding methodological inadequacies in the face of modern demands, and language barriers, it would be unfortunate to ignore them. When they are not ignored, compilations are available. Several animal models allow various experiments that highlight the interest of phage therapy. In human medicine today, it is mostly individual cases treated on a compassionate basis that are reported in Western literature. For our part we treated a few patients whose functional prognosis was engaged. They are reported in Table I.

If we take into account the time since 1922, when the first publication relates a therapeutic trial by bacteriophages in furunculosis [3], we can say that almost all pathologies of bacterial origin, whatever the infection site, have been treated by bacteriophages. Even if pragmatism prevailed then, important clinical series were reported, notably in the countries of the East $[69,70]$ and in France France where André Raiga [71] was the most ardent defender of phage therapy. He was a surgeon who practiced in Paris and who published articles reporting important series of patients treated [72] for various types of infections (bone, urinary, etc ...) with various bacteria. But if we consider that these examples are insufficient in view of the current requirements of perfectly codified clinical studies, the results and remarks that have been presented still appear relevant.

Two circumstances can be envisaged, that in which phage therapy can be applied locally (localized infection accessible directly or surgically) and that where only a parenteral treatment is appropriate (meningitis, septicaemia, etc.).

\section{a) Gastro-intestinal infections}

First indication, proposed as early as 1919 by Félix d'Hérelle, bacterial gastroenteritis has been treated successfully for a long time, including shigellosis, salmonellosis, cholera, etc ... Currently these diseases are not a concern in countries where hygiene is developed, but in countries where access to drinking water is difficult, epidemics are sometimes very deadly. The Brussow's team [73] treated $E$. coli infections using [74] a specific pharmaceutical preparation that contains 18 bacteriophages marketed in Russia (IntestiPhage TM, MicroGen).

Perfectly tolerated, it would seem that this is an indication to be considered but the result is difficult to predict. Indeed, oral administration of bacteriophages is easy (after alkalization of the stomach or appropriate vectorization) and without any side effects. But we must take into account antagonistic factors that are sometimes difficult to control. Gastric acidity is a hostile barrier to ingested bacteriophages. To overcome this drawback, two possibilities are conceivable: alkalinisation by administration of an alkaline liquid (bicarbonate water, carbonated water) or gastro-resistant vectorization. But beyond this barrier, the gut microbiota constitutes an interactive, competitive and complex environment that makes the treatment outcome uncertain [75]. However, interestingly, the treatment has no side effect on the gut microbiota that seems little impacted.

It is now known that the human intestinal virome is individual, stable and dominated by bacteriophages. It develops quickly after birth with the microflora communities. Inflammatory disease 
of the digestive tract such as Crohn's disease or ulcerative colitis is manifested by a microbial imbalance (dysbiosis). Could bacteriophages help restore this balance? Many studies are starting in this direction [76-78].

Currently in Western countries Clostridium difficile is a major problem (diarrhea and transmission within the community) against which conventional antibiotics are not very effective. Many authors in recent years have considered fighting this bacterium with bacteriophages. An interesting fact has been revealed in vitro, a strong adsorption of bacteriophages on a model of human cells, which would promote bacteriophage-bacterial interactions [79]. Note also the interest of using an optimized cocktail of bacteriophages [80]. Finally, as suggested in one case study [81], could one hypothesize that faecal microbiota transplants in this indication might represent an effective treatment by the implantation of specific bacteriophages present in the donor [82]?

\section{b) Localised infections}

Whether superficial (cutaneous or mucous) or deep, these infections are caused by many bacterial species.

\section{Skin and soft tissues - Superinfected wounds}

Although not life-threatening and rarely fatal, many chronic skin infections may require longterm antibiotic treatment. This helps to disrupt microbiomes and select antimicrobial resistance. Phage therapy of acne may prevent prolonged use of antibiotics [83].

Staphylococcal skin infections, among the first to benefit effectively from bacteriophage treatment [3], do not appear as the priority indication in Europe today, unlike the situation in the United States where the very high incidence of MRSA (Methicillin Resistant Staphylococcus aureus) requires solutions. In the current context, the wounds of infected war veterans, particularly in Afghanistan and Iraq with Acinetobacter baumannii, have highlighted the need to find alternatives to antibiotic therapy[84]. Bacteria associated with extensive burns (Pseudomonas aeruginosa, E. coli and $S$. aureus) have become multiresistant and the mortality rate is high among these patients. Conventional methods of treatment [85] having shown their limit, other treatments are being sought. An experiment by application of topical bacteriophage was conducted in Belgium [86] and another one in France [87]. Although the first study showed no adverse effects, the limited "clinical trial" in terms of number of subjects failed short of properly verifying the efficacy of the bacteriophage cocktail that was used (anti $P$. aeruginosa and $S$. aureus). Let us hope that the French study (European multicenter study Phagoburn [88]) being currently analysed can provide this information. There is also a recent individual case of superinfection from a rare chronic cutaneous disease (Netherton syndrome) which demonstrate the value of phage therapy [89].

\section{Deep-seated infections}

Anaerobic bacteria can infect surgical wounds in the abdomen or following accidental trauma. While bacteriophages for these bacteria exist or can be easily isolated [90], they are still of little interest because of the limited failure rate of conventional treatments. In deep-seated local infections surgical debridement [91] is a preferred prerequisite before treatment with either antibiotic or phage therapy, especially in S. aureus [92] or Propionibacterium sp. [93] infections on implants.

\section{c) Osteoarticular infections}

These infections are a particular form of deep-seated localised infections but given their frequency and difficulty in responding to antibiotic therapy they are a prime target for phage therapy. The diffusion of antibiotics into the bone tissue is often mediocre and impaired by the presence of bacterial biofilms that form at the contact between bone and prosthetic material. Recurrence and the transition to chronicity is more and more common for many reasons including the presence of 
multidrug-resistant bacteria. Today, the number of post-surgical bone infections on fracture or joint prosthesis continues to increase [94]. Conventional treatments are long and costly, with frequent repeat surgery and sometimes amputation is the only outcome [95].

Phage therapy has been used very early and very frequently in this type of infection, as evidenced by innumerable publications across the Atlantic [96] and in Eastern European countries [97,98]. In France the surgeon André Raiga [72,99] made several assessments of his long experience in this field. More recently, a Strasbourg clinical study was published in 1979 [100].

An experimental model [101] has demonstrated that a treatment combining bacteriophages and antibiotics helps to dissolve the biofilm with a pronounced effect on the biofilm of Staphylococcus sp. compared to that of Pseudomonas aeruginosa. It should be added that diabetic foot infection, a very frequent complication, also present a clinical situation that has highlighted the efficacy [102] of bacteriophage-antibiotic co-therapy [103]. In recent years, experimental animal studies have multiplied and shown the interest of this approach. We recommend the review of Akanda et al. [104] which particularly emphasizes the advantages of phage therapy in the case of peri-prosthetic infections especially when associated with antibiotic therapy.

Post accidental and / or surgical osteitis is often caused by Staphylococcus aureus which is often an MRSA. Following a prolonged evolution, fistulas frequently appear and amputation is sometimes proposed as a radical solution. It is therefore not surprising to note that there has been for several years a very large number of experimental studies on this subject both in vitro and in vivo in animals $[105,106]$. Nonetheless, we can only be surprised (to put it mildly) that in human medicine phage therapy is not by now systematically used, except only recently and in clinical cases where the vital or functional prognosis is dire. This is a real emergency in a context where we still do not have a GMP labelled bacteriophage suspension. Human experimental studies cannot be initiated until a GMP compliant production is available. Such preliminary work has been undertaken by the company Pherecydes Pharma in collaboration with the French regulatory and health authorities. Moreover, in France a budget has been allocated to the PhagOs study [107], which will start as soon as GMP compliant suspensions are available.

\section{Specific case of the diabetic foot}

Diabetic foot ulcer infections are a growing problem in public health, with increasing prevalence, poor antibiotic response, and bacterial resistance to traditional antimicrobials that lead to morbidity and mortality. Phage therapy would seem to be an interesting complementary solution [108]. A small clinical study on compassionate ground of phage therapy in nine patients with diabetes and toe ulcers infected with $S$. aureus has just been presented [109]. Topical application of a mono-bacteriophage against $S$. aureus has been successfully used to treat ulcerations with bone involvement despite poor vascularization and failure of antibiotic therapy. In France, an experimental clinical study called PhagoPied (Pherecydes Pharma) has been budgeted and should be operational this year.

\section{d) Urinary tract infections}

Infection of the lower urinary tract is common with E. coli as the first responsible bacteria. While many successes have been reported in countries such as Poland and Russia, controlled clinical studies are absent in Western countries to demonstrate the full potential of bacteriophages in these infections.

In the past it is an indication that has been described with many successes and very early in France [110] where a specific suspension of bacteriophage was injected subcutaneously (1.5 to $2 \mathrm{~mL}$ ) and accompanied with bladder instillation and / or oral absorption. Taking into account the results, an evaluation was carried out in the United States [111,112] and recommendations were specified [113]. Phage therapy of urinary tract infections was then overshadowed by antibiotic therapy. This type of infection is not considered an emergency and researchers have little interest in the problem. There is a 
lack of properly controlled clinical studies to demonstrate the potential of bacteriophages in this indication.

Interest has again appeared recently in countries of Eastern Europe (Poland) and Russia. Clinical cases have been reported [114], among others, among patients treated with Pyo-bacteriophage ${ }^{\circledR}(4$ cases with E. coli and 1 with P. aeruginosa) in a double-blind, randomized, placebo-controlled clinical trial. According to Sybesma et al. [115], phage therapy appears to be a promising treatment for urinary tract infections as long as the bacteriophage suspension is adapted to the patient's strains as not all strains are sensitive to commercial suspensions. The most commonly encountered bacteria are: Enterococcus faecalis, Proteus mirabilis, E. coli, K. pneumoniae, P. aeruginosa. One of us has been involved in the treatment of failed cystitis caused by $P$. aeruginosa [116] following multiple antibiotic treatments.

A new development is the description of a urinary microbiome in asymptomatic "healthy" normal individuals [47]. After finding a quantitative and qualitative variation in bacteriophages among individuals with urinary symptoms one might think that, like in the case of bacteriophages of the intestinal tract, bacteriophages present in the bladder could ensure the protection of the urinary tract.

It should also be mentioned that chronic urinary tract infections, despite the progress made in recent years, are still numerous [117] and responsible for the formation of dense biofilms on catheter surfaces that block urinary evacuation [118], as is the case with infections caused by Proteus mirabilis.

\section{Specific case of bacterial prostatitis}

This is a particular aspect that deserves consideration given its frequency and the resistance of bacteria to antibiotics, which, moreover, diffuse poorly in prostatic tissue. Worth noting are the small Polish clinical study [119] of a rectal treatment for chronic prostatitis caused by Enterococcus faecalis and the review published by the same authors [120]. Chronic infections are frequent and resistant to treatment. The rectal route seems to allow healing as this small clinical study has been shown. Could prostatic infections caused by E. coli or P. aeruginosa also benefit from a phage therapy combining rectal and / or oral administration? Due to its frequent occurrence, it is worth noting a phage therapy clinical study on 27 urinary tract infections after transurethral prostatic resection treated experimentally compared to 27 control subjects [121].

\section{e) Respiratory tract infections}

Chronic respiratory infections are of grave medical concern because of the high degree of patient mortality. Associated with chronic respiratory pathology, colonization by a bacterium can indeed lead to a serious respiratory decompensation if it is not controlled. An experimental study, conducted in mice, has shown that a virulent bacteriophage introduced nasally prevents a deadly form of pulmonary infection (100\% survival rate against 100\% mortality in control animals) [122]. Inhalation seems to be effective in delivering lyophilized bacteriophages to the lungs in the form of powder propelled by inhalers [64]. The bronchopulmonary tree is indeed easily accessible by air. But few cases have been published so far [123]. Thus, it is conceivable to spray bacteriophage suspensions (nebulization, misting) or dry forms (spray) [65]. Some isolated cases [124,125] are rare examples of recent successful treatments. However, in the experimental PneumoPhage study by Pherecydes Pharma [126] the results, although not published, seem promising. Pseudomonas aeruginosa is not the only bacterium found in such infections and it is necessary to consider many species of enterobacteria (Klebsiella pneumonia, E. coli, etc ...), or other Gram-negative bacteria (Acinetobacter baumannii, Achromobacter sp., etc ...) or Gram-positive bacteria (Staphylococcus sp. but mainly Streptococcus $s p$., in particular Streptococcus pneumoniae). The lung is vulnerable to many occasional opportunistic environmental bacteria. Bacteriophages have been isolated for almost all of these bacteria and sometimes tested in experimental models, but their use in human pathology using appropriate vectorization for inhalation [127] remains to be evaluated. 


\section{Specific case of cystic fibrosis}

One of the indications for phage therapy is the treatment of superinfections caused by cystic fibrosis, mainly due to Pseudomonas aeruginosa. Cystic fibrosis, although not an infectious disease in itself, is the subject of special attention because of the chronic state of the repetitive superinfections that occur in young people who have it. Cystic fibrosis is usually superinfected by mucosal $P$. aeruginosa strains that are resistant to many antimicrobials and capable of forming biofilms. If bacteriophages can provide relief in these conditions, inhalation appears to be the simplest form of administration for successive treatments. This requires the development of a vectorization that is not without drawbacks but is the subject of very active research. Regular microbiological monitoring is required to search for new bacteriophages active on $P$. aeruginosa strains.

\section{Specific case of pulmonary tuberculosis}

Infections caused by Mycobacterium tuberculosis affect many organs, mainly the lungs. To take into account the peculiarities of this bacterial genus (slow growth and intracellular multiplication), we will see below (paragraph: infections and difficult targets) that these pathologies require a particular approach.

\section{f) Systemic infections}

Although septicaemia and meningitis have been treated, sometimes with success, it seems premature to consider such indications for phage therapy for at least two reasons: the urgency of treatment and the need for parenteral treatment. While it has been shown that bacteriophage can be adapted to allow their injection to be tolerated [128], it is known that rapid diffusion from the serosa (peritoneum, pleura) could prevent IV injection.

\section{Meningitis}

As early as 1932 bacteriophages were used to treat this pathology [129]. In the 1940s, MacNeal reported several cases [130] of meningitis including some caused by Staphylococcus $s p$. treated by combining bacteriophage and sulfathiazol (a sulfonamide derivative). More recently, we should also mention the French [131,132] and Polish [133] publications reporting cases of human meningitis medical or post-traumatic associated with various bacteria (E. coli, P. aeruginosa, etc ...).

\section{Cardio-vascular infections; septicaemia}

André Raiga, like Ward J. MacNeal already mentioned, had reported in the early 1930s cases of sepsis cured by adapted phage therapy [134,135]. These same authors [136] also presented cases of thrombosis of the cavernous sinus, particularly dangerous in terms of prognosis. It is worth noting in 1978 the treatment of Serratia endocarditis by bacteriophages [137] and recently a P. aeruginosa septicaemia in a 2-year-old child with a combination of two bacteriophages[138]. Some of these infections have benefited from intravenous injections of bacteriophages without significant side effects. Healing of a chronic P. aeruginosa infection from an aortic Dacron graft with cutaneous fistula has recently been reported [19]. A single application of a bacteriophage associated with ceftazidime, allowed the resorption of the infection that could not solely be controlled by antibiotic treatment. The bacteriophage was selected to bind to the proteins of the $P$. aeruginosa efflux pump which, while ensuring the destruction of the bacteria, avoided the selection of antibiotic-resistant strains. Speck and a. [139] contend that these infections are excellent candidates for use of intravenous phage therapy.

\section{g) ORL, stomatology and ophthalmology}

These specialties present infectious pathologies that allow local treatments by phage therapy. Otitis, sinusitis, conjunctivitis, and periodontitis have been successfully treated. 


\section{Otitis}

In acute otitis the bacterium in question is often a Pneumococcus sp. (for which bacteriophages have been isolated) but in chronic forms $P$. aeruginosa is a problem given its resistance to antibiotics. The recent experimental study by Wright et al. [140] comprises 12 patients with chronic otitis media caused by $P$. aeruginos $a$ and treated with $200 \mu \mathrm{L}$ of a cocktail of 6 bacteriophages. Compared to 12 placebo-treated patients, the treatment was found to have some efficacy without side effects. To obtain a cure, however, prolonged treatment seems necessary.

\section{Sinusitis}

Chronic rhinosinusitis affects 5 to $15 \%$ of the world's population. In some patients, the infectious exacerbation of the disease does not respond to conventional treatments. These cases are probably associated with the presence of bacterial biofilms [141]. Multidrug-resistant $S$. aureus is often responsible and both infected sinuses and upper air cavities seem amenable to treatment by bacteriophages [142,143]. In chronic forms, which are frequent and resistant to antibiotic therapy, the significant interest of using bacteriophages that reduce biofilms has been highlighted [144].

\section{Ophthalmology}

This indication was not often considered [145], as Gorski's review [146] points out, even though it was used in a recent French individual case in Georgia [147]. According to the articles from Eastern European countries regarding superficial infections (conjunctivitis, blepharitis) with Staphylococcus $s p$., it is advisable to apply 2 drops 3 times a day. Patients seem to tolerate such a dosage perfectly well.

\section{Stomatology}

The bacteriophages that make up the microbiome of the oral cavity are the object of more and more frequent studies [148,149] suggesting the possibility of considering the treatment by bacteriophages of bacterial infections in stomatology and dentistry $[150,151]$.

\section{h) Difficult infections and pathogens}

Infections with pyogenic bacteria that we have considered previously represent a very large number of pathologies for which phage therapy seems to be able to provide a rapid solution. Some infections are caused by unusual bacteria taking advantage of the decrease in individual natural defences. These opportunistic bacteria are often multidrug-resistant and ready-to-use bacteriophage suspensions are generally not immediately available for such situations. The answer is to set up pharmacies stocking bacteriophages that could be used for authorized supply and / or preparations of bacteriophage suspensions [152]. A network relationship of several biobanks would enhance the potential of this approach. Other infections with specific bacteria present additional obstacles of various kinds. One of these obstacles is the preferential intracellular location of bacteria (macrophage or epithelial cell), for example mycobacteria in tuberculosis. In these situations, vectorization (encapsulation in a liposome for example [153]) might solve the problem.

Let us mention, for the record, some bacteria that cause infections that are difficult to control [154] for which the question of the interest of phage therapy is repeatedly raised. A few teams have looked at some of them, but it is still too early to draw any conclusions: more specifically, infections caused by: Helicobacter [154,155]; Borrelia (Lyme disease [156]) as well as Brucella, Yersinia pestis and Bacillus anthracis [157] in the context of biological weapons risk [158], etc ... Other bacterial species (Haemophilus influenzae, Streptococcus pneumoniae) do not generate much interest today for phage therapy application. It should be noted that Campylobacter bacteriophages are mainly studied in poultry farms in a preventive context rather than therapeutically. 


\section{5) Our own experience}

\section{a) Arguments for a reintroduction of phage therapy}

Our personal experience dates back to the $1980 \mathrm{~s}$, when it was still possible to obtain from two Pasteur Institutes suspensions of therapeutic bacteriophage adapted to the pathogenic bacterium of a patient. The experience of our correspondents had been summarized shortly before in a paper outlining their conclusion (Box 2) [32]. For a few years, we had then been able to form an opinion on the interest of this therapy which was still routinely performed in some hospitals such as in Strasbourg. A surgical service had published a small clinical study of 7 cases and concluded that phage therapy was promising, particularly in bone infections (see Box 3) [100]. Several patients in our hospital with bone infections in whom conventional treatment had failed had also benefited from such phage therapy treatment (unpublished results). But by the late 1980's, phage therapy became less available and it was impossible for us to continue this practice. There followed a period of about two decades during which phage therapy had become inaccessible in France.

\section{Box 2 : Conclusion of Vieu et al.}

The growing importance of opportunistic bacteria resistant to antibiotics in infectious pathology has oriented the therapeutic applications of bacteriophages to three new areas:

1) the curative treatment of postoperative surgical infections,

2) suppression of the infectious process during gram-negative paediatric epidemics,

3) curative treatment of chronic urinary tract infections

\section{Box 3 : Conclusion of Lang et al.}

The use of suitable bacteriophages in the treatment of antibiotic-resistant chronic bone infections seems to us to be an interesting therapeutic alternative. Our results fully encourage us to continue in this direction.

Of course, one could object that the use of bacteriophages alone has never provided a cure. But we should note that these were chronic cases having exhausted the usual therapeutic arsenal. We have not sought here to do virological experimentation but to treat patients. As orthopaedic surgeons aware of the dreadful chronicity of osteitis, we wanted to put all the chances on the side of our patients and it appears to us that the good results obtained thanks to the bacteriophages are more constant than those expected from conventional treatments.

In 2005 we were able to buy over-the-counter commercial preparations of bacteriophages from pharmacies in Moscow for a few dozen Euros. After an evaluation (sterility, activity, specificity) of these preparations [159], we retained those capable of responding to the problems we encountered. In the particularly worrying case of an evolutionary infection of the external auditory canal, a bacteriophage suspension against $S$. aureus was used to treat chronic otitis externa (Box 3) [160] and table I (first line 1- AC). Within 72 hours there was a spectacular resolution of the hyperalgesia symptoms and the disappearance of the otorrhea.

\section{Box 4 : Treatment of an external otitis.}

A young patient was examined for the first time for chronic otitis after episodes of repeated otitis treated with various antibiotics. The specialist noted an otorrhea and decided to treat it medically (cefpodoxime and ofloxacin) before surgery. Repair of the tympanic membrane was performed. The immediate treatment outcome was simple.

After three months the otorrhea reappeared. The examination was particularly difficult because of very sharp local pain. The eardrum became inflamed and wet. The resumption of local antibiotic therapy (bacitracin) helped reducing the pain.

During one year, the patient experienced several treated otorrheas (ofloxacin). During a discharge consultation with acute pain and under general anaesthesia, a specimen was collected showing the presence in pure culture of $S$. aureus (resistant to penicillin R, methicillin-R, 
erythromycin-R and ofloxacin- R). Despite antibiotic therapy immediately prescribed, the purulent flow and pain persisted, and the Staphylococcus was still present.

It was then decided to carry out a more precise examination and to collect multiple specimens (tympanic membrane, cutaneous coating of the external duct) before the local application to the pathogen of a bacteriophage suspension active in vitro, in combination with pristinamycin.

Within 48 hours, the patient noticed a clear improvement: cessation of purulent flow and pain. Subsequent consultations confirmed the favourable course: absence of otorrhea or pain and disappearance of Staphylococcus. After three months, the ear examination was still very satisfactory and the treatment was stopped.

With this experience and in the face of increasing therapeutic failures that we were confronted with especially in orthopaedic surgery, we decided to reintroduce phage therapy from 2008 in the hospital where we practiced. 


\begin{tabular}{|c|c|c|c|c|c|c|}
\hline $\begin{array}{l}\text { Patient } \\
\text { (1) }\end{array}$ & $\begin{array}{c}\text { Sexe } \\
(2) \\
\end{array}$ & Clinical symptoms & Bacteria & $\begin{array}{c}\text { Age } \\
\text { (3) }\end{array}$ & Phage therapy & Outcome \\
\hline $1-\mathrm{AC}$ & $\mathrm{F}$ & $\begin{array}{l}\text { 2004- Suppurating chronic } \\
\text { otitis; intense pain }\end{array}$ & S. aureus & 20 & $\begin{array}{l}\text { 2006- Commercial anti-Staphylococcus } \\
\text { aureus suspension; ear drop instillations (15 } \\
\text { days) }\end{array}$ & 2006- Complete cure \\
\hline 2- HL & $\mathrm{H}$ & $\begin{array}{l}\text { 2005- Accidental fall causing } \\
\text { multiple fractures ( } 37 \text { fractures); } \\
\text { amputation considered }\end{array}$ & S. aureus & 44 & $\begin{array}{l}\text { 2008- Commercial anti-Staphylococcus } \\
\text { aureus and Pyophage suspensions; } \\
\text { administered peroperatively over several } \\
\text { weeks }\end{array}$ & $\begin{array}{l}\text { August 2009- Wound closure and } \\
\text { complete cure }\end{array}$ \\
\hline 3- GC & $\mathrm{H}$ & $\begin{array}{l}\text { 2007- Road accident causing } \\
\text { multiple trauma and leading to } \\
\text { uncontrolled pelvic bone } \\
\text { infection }\end{array}$ & $\begin{array}{l}\text { S. aureus } \\
P \text {. aeruginosa }\end{array}$ & 25 & $\begin{array}{l}\text { 2008- In-house phage suspension anti- } \\
\text { Staphylococcus aureus and anti- } \\
\text { Pseudomonas aeruginosa; administered } \\
\text { peroperatively and via catheter in the days } \\
\text { following the operation }\end{array}$ & October 2010- Complete cure \\
\hline $4-\mathrm{PI}$ & $\mathrm{F}$ & $\begin{array}{l}\mathbf{2 0 0 8} \text { - Multiresistant bacterial } \\
\text { infection associated with a } \\
\text { bladder stent. Unsuccessful } \\
\text { ciproflaxin treatment over } \\
\text { several months and requiring } \\
\text { patient hospitalisation, with } \\
\text { increasingly poor prognosis }\end{array}$ & P. aeruginosa & 69 & $\begin{array}{l}\text { 2008- Tailored anti-P. aeruginosa } \\
\text { suspension prepared against patient isolate } \\
\text { in Tbilisi (Georgia) and administered in } \\
\text { Sydney (Australia) by instillation via } \\
\text { urinary catheter over } 10 \text { days. Additional } \\
\text { antibiotic therapy initiated after } 6 \text { days to } \\
\text { prevent nosocomial opportunistic infections }\end{array}$ & $\begin{array}{l}\text { 2009-Complete cure. Patient was } \\
\text { discharged to spend Christmas } \\
\text { with her family. No remaining } \\
\text { urinary infection, even at } 6 \text { months } \\
\text { follow up }\end{array}$ \\
\hline 5- CL & $\mathrm{F}$ & $\begin{array}{l}\text { 1995- Fall leading to complex } \\
\text { fracture of the right foot } \\
\text { 2008- Planned amputation }\end{array}$ & S. aureus & 40 & $\begin{array}{l}\text { 2009- Commercial anti-Staphylococcus } \\
\text { aureus suspension; administered } \\
\text { peroperatively and via catheter in the days } \\
\text { following the operation }\end{array}$ & $\begin{array}{l}\text { November } 2009 \text { - Wound closure } \\
\text { and complete cure }\end{array}$ \\
\hline 6-PD & $\mathrm{H}$ & $\begin{array}{l}\text { 2008- Fistulised abdominal } \\
\text { plaque infection; continuous } \\
\text { suppressive antibiotic } \\
\text { administration }\end{array}$ & $\begin{array}{l}\text { S. aureus } \\
\text { (MRSA) }\end{array}$ & 60 & $\begin{array}{l}\text { 2009- Commercial anti-Staphylococcus } \\
\text { aureus suspension administered via the } \\
\text { fistula }\end{array}$ & $\begin{array}{l}\text { No recurrence without any } \\
\text { antibiotic over } 4 \text { years }\end{array}$ \\
\hline $7-X$ & $\mathrm{~F}$ & $\begin{array}{l}\text { 2008- Knee prosthesis infection } \\
\text { unsuitable to surgery }\end{array}$ & P. aeruginosa & 80 & $\begin{array}{l}\text { 2010- Commercial broad spectrum multi- } \\
\text { bacteriophage suspension; Knee joint } \\
\text { injection }\end{array}$ & $\begin{array}{l}P . \text { aeruginosa disappearance but } \\
\text { appearance of Enterococcus } s p \text {. }\end{array}$ \\
\hline
\end{tabular}




\begin{tabular}{|c|c|c|c|c|c|c|}
\hline 8- MT & $\mathrm{F}$ & $\begin{array}{l}\text { 1995- Operated tongue cancer } \\
\text { 2005- Dental extraction, jaw } \\
\text { fracture, osteo-synthesis and } \\
\text { fistulised infection }\end{array}$ & $\begin{array}{l}\text { S. aureus } \\
\text { (MRSA) }\end{array}$ & 61 & $\begin{array}{l}\text { 2010- Commercial anti-Staphylococcus } \\
\text { aureus suspension administered } \\
\text { peroperatively }\end{array}$ & Complete cure of the infection \\
\hline 9- RM & $\bar{F}$ & $\begin{array}{l}\text { 16/12/2009: Femoral fracture } \\
\text { under hip prosthesis } \\
\text { 19/01/2010: Drained } \\
\text { hematoma. Antibiotherapy } \\
\text { 27/01/2010: infection }\end{array}$ & $\begin{array}{l}\text { S. aureus } \\
\text { (MRSA) }\end{array}$ & 90 & $\begin{array}{l}\text { 2010- Commercial anti-Staphylococcus } \\
\text { aureus suspension administered } \\
\text { peroperatively by flooding the infection site } \\
\text { and via catheter in the } 10 \text { days following the } \\
\text { operation }\end{array}$ & $\begin{array}{l}\text { Complete cure and rapid recovery } \\
\text { without recurrence after } 1 \text { year } \\
\text { with retention of the hip prosthesis } \\
\text { and osteosynthesis material in-situ. }\end{array}$ \\
\hline 10- ML & $\mathrm{M}$ & $\begin{array}{l}\text { 2012- Ulcerative } \\
\text { Colitis/Chronis with liver } \\
\text { complications. Severe weight } \\
\text { loss ( } 54 \mathrm{~kg} \text { down from } 80 \mathrm{~kg} \text { ). } \\
\text { Poor digestion of food. }\end{array}$ & $\begin{array}{l}\text { E. coli, Proteus } \\
\text { spp., } \\
\text { Staphylococcus } \\
\text { aureus (Urine) } \\
\text { S. aureus (skin) } \\
\text { E. coli, Proteus } \\
\text { vulgaris, Proteus } \\
\text { mirabilis (stool) }\end{array}$ & 20 & $\begin{array}{l}\text { 2012- Treatment in Tbilisi (Georgia) with } 2 \\
\text { commercially available phage suspensions } \\
\text { plus special customised phage suspension. } \\
\text { Probiotics, enzymes and Camelyn immune } \\
\text { stimulant also given. Treatment lasted } 1 \\
\text { month }\end{array}$ & $\begin{array}{l}\text { Healing with sterilisation of the } \\
\text { urine, reduction of } E \text {. coli and } P \text {. } \\
\text { vulgaris growth from high }\left(10^{8}\right) \text { to } \\
\text { low }\left(<10^{2}\right) \text { in stool. Weight gain to } \\
72 \mathrm{~kg} \text { by end of treatment. } \\
\text { Digestion of food improved but } \\
\text { still poor }\end{array}$ \\
\hline 11- NP & $\mathrm{F}$ & $\begin{array}{l}\text { 2009- Left knee prosthesis } \\
\text { infection }\end{array}$ & $\begin{array}{l}\text { Staphylococcus } \\
\text { sp. }\end{array}$ & 72 & $\begin{array}{l}\text { 2013- Commercial anti-Staphylococcus } \\
\text { aureus suspension administered } \\
\text { peroperatively by flooding the infection site }\end{array}$ & $\begin{array}{l}\text { Initial partial disinfection with } \\
\text { closure of several fistula followed } \\
\text { by stabilisation }\end{array}$ \\
\hline $12-\mathrm{JH}$ & $\mathrm{H}$ & $\begin{array}{l}\text { 1943- Osteomyelitis of the left } \\
\text { tibia } \\
\text { 2012- Fistula next to the wound }\end{array}$ & $\begin{array}{l}\text { S. aureus } \\
\text { (MRSA) }\end{array}$ & 84 & $\begin{array}{l}\text { 2013- Initial phage therapy treatment in } \\
\text { Tbilisi (Georgia) via fistula with temporary } \\
\text { improvement, followed by surgical follow } \\
\text { up intervention in France on } 3 / 12 / 2013 \text { : } \\
\text { Commercial anti-Staphylococcus aureus } \\
\text { suspension administered peroperatively by } \\
\text { flooding the infection site }\end{array}$ & Complete cure \\
\hline 13- MC & $\mathrm{H}$ & $\begin{array}{l}\text { 2015- Osteosynthesis for right } \\
\text { knee fracture }\end{array}$ & S. aureus & 67 & $\begin{array}{l}\text { 2013- Infection site cleaning with phage } \\
\text { suspension during surgery }\end{array}$ & $\begin{array}{l}\text { Disappearance of } S . \text { aureus } \\
\text { replaced by } P \text {. aeruginosa and } \\
\text { Streptococcus constellatus, } \\
\text { followed by complete cure without } \\
\text { recurrence }\end{array}$ \\
\hline $14 \mathrm{AB}$ & $\mathrm{F}$ & $\begin{array}{l}\text { 2000- Acoustic neuroma with } \\
\text { nosocomial infection of the } \\
\text { ENT and ophthalmic regions }\end{array}$ & S. aureus & 58 & $\begin{array}{l}\text { 2013- Treatment in Tbilisi (Georgia) with } \\
\text { locally produced phage suspensions } \\
\text { administered locally and orally }\end{array}$ & $\begin{array}{l}\text { Complete cure allowing an } \\
\text { ophthalmic intervention of the } \\
\text { retina that had been delayed for } \\
\text { several years }\end{array}$ \\
\hline
\end{tabular}




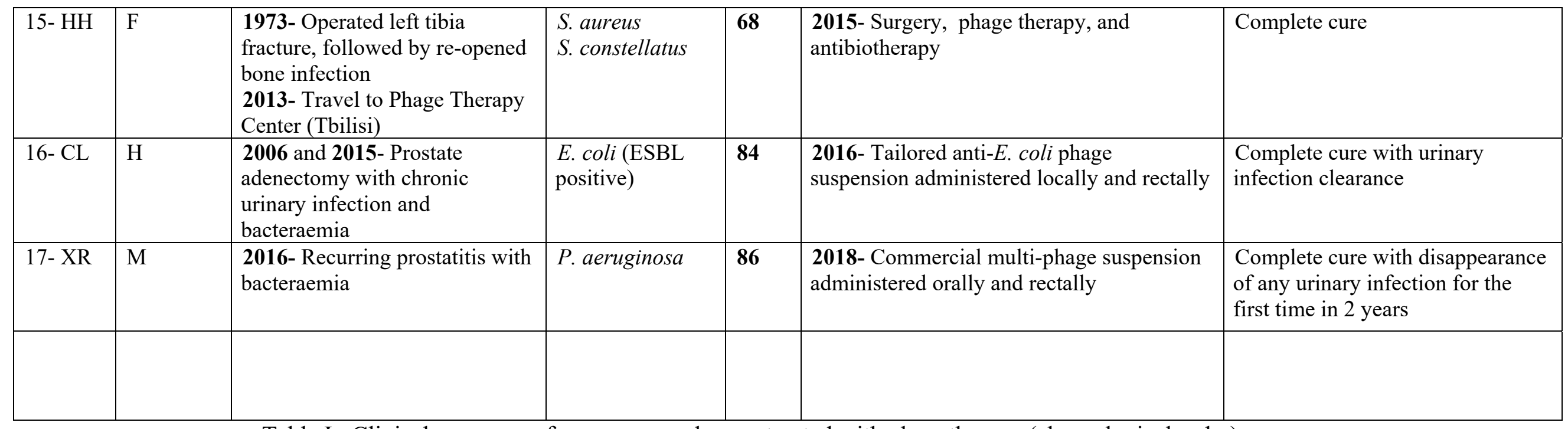

Table I : Clinical summary of some personal cases treated with phagotherapy (chronological order)

(1) patient initials ; (2) F (women) - M (man); (3) age (year) at the time of phagotherapy 


\section{b) Methodology}

\section{Before patient admission}

The decision was made by a multi-disciplinary hospital team (surgeon, infectious disease specialist, microbiologist) to conduct a complete examination of the patient and his file. In addition to the biological assessment, one or more preliminary specimens were taken to isolate the bacterium and test its sensitivity to available bacteriophages.

\section{Therapeutic care}

If necessary, the infectious foci were excised (debridement) and cleaned during an intervention in the operating room. One or more intraoperative specimens were collected to confirm the initial bacteriological diagnosis. At the end of the intervention before closure of the operative field, the cocktail of bacteriophages was used to flood the operative field ( 5 to $10 \mathrm{ml}$ according to the surface of the field). Access to the treatment site (opening or drain) allowed a bacteriological control and to introduce the same cocktail in the days following the intervention.

Antibiotic therapy reflecting the pathogen's antibiotic resistance profile was used in combination with phage therapy and the patient was kept under surveillance for a few days (less than one week) to ensure that there was no evidence of infection (local, biological or bacteriological). The postoperative course was simple and no side effects were reported.

\section{Follow up}

Ambulatory monitoring was performed in our facility for several months at a variable frequency. The evaluation of each case was performed clinically as well as biologically and radiologically. Some patients, despite being followed medically, provide us with their news which so far have been excellent.

\section{c) Analysis of the reported clinical cases}

All cases reported here (Table 1) have benefited from compassionate phage therapy for treatment failure duly recorded. The phage therapy treatments were carried out between 2006 and 2018 after a long evolution, generally several years, of a conventional treatment according to the official medical guidelines. All the patients had benefited from multiple attempts at treatment (surgical interventions and antibiotic therapy) and had been in therapeutic failure for months or even years. Some had previously tried treatment at the G. Eliava Institute in Tbilisi.

Overall, the infectious sites were predominantly osteoarticular (10/15), but two cases involved the prostate and the other 3 various infections including otitis (Box 3). The predominantly targeted bacterial species was multidrug-resistant Staphylococcus aureus (MRSA) but not always, more rarely Pseudomonas aeruginosa and only once Escherichia coli. Most often it was a mono-microbial infection. Suspensions of bacteriophages were mainly from commercial sources (MicroGen in Russia and Eliava Institute in Georgia). In the absence of available commercial preparations, two cases were treated with tailored bacteriophage suspensions.

This small series of cases calls for some remarks. We found that local application of bacteriophages is completely safe and no accidents or incidents have been reported. We have observed satisfactory results and often rapid improvement. The administration of bacteriophages has always been accompanied by antibiotic therapy. Note that these were chronic cases having exhausted the usual therapeutic resources. We did not try to experiment but instead to treat patients.

The pathologies that have been treated are varied. In our small case study bone infections were the most frequent and have evolved favourably within a few weeks. If there were fistulas, they disappeared, bone consolidation was observed clinically, functionally and confirmed by imaging. The 
bacteria became quickly undetectable. After a follow up for some patients of over 10 years, no relapse has been observed and it is possible to talk about complete healing. In two cases where amputation of the lower limb was being considered, this option was avoided. Treatments that prevented ablation of prosthetic material were also satisfying.

Let's emphasize again the treatment of two prostatitis which constitute the most recent cases that we have taken care of. Infections with E. coli in one case and P. aeruginosa in the other affecting elderly people had been undergoing antibiotic therapy for several months. Concomitant oral and rectal administration over 2 consecutive days in one case and over 3 days for the other resolved the recurrent infectious problem.

\section{6) Conclusion and future perspectives}

Noting a continuing increase in bacterial resistance to antibiotics and the scarcity of new antibiotic molecules, the World Health Organization declared in 2014 that a pre-antibiotic era was imminent [161] and that there was an urgent need worldwide to mobilize international cooperation. In view of the risk to public health, new strategies need to be considered without delay. Phage therapy is one of them, probably the most successful today. But although it is the object of several thousand publications, phage therapy must be reconsidered in the light of new knowledge, often very recent, concerning the bacteriophages. It would be regrettable if innumerable observations were not taken into account $[162,163]$, some of which have been published decades ago and constitute a prime source of information. Further research is needed to better understand the biology of bacteriophages, their behaviour in the natural environment as well as in the human body, as well as the parameters that affect their interactions with their bacterial hosts. But above all, the introduction of bacteriophages as anti-infectives requires the definition of a regulatory framework for their manufacturing. However, from the perspective of sustainable development, it will be necessary to use bacteriophages carefully and take into account multiple parameters [164]. A multidisciplinary approach is more than ever needed, bringing together microbiologists, ecologists, specialists of the evolution of microsystems [165], infectious physicians, surgeons, etc... If it is unlikely that phage therapy will ever replace antibiotic therapy, faced with the potential threat caused by bacteria, it would surely be best to combine available weapons to best fight them. Be that as it may, care must be taken not to reproduce the same errors as those perpetrated with antibiotic therapy and strictly control the use of phage therapy.

Phage therapy was introduced for the first time almost a century ago, first in France and then rapidly in several countries of the world. When first used, knowledge of bacteriophages was limited and their therapeutic introduction was empirical like many treatments at that time. Recently, we have ourselves used phage therapy empirically in compassionate cases and reconfirmed its interest. Based on this experience and after reviewing the literature, we believe that the field of osteoarticular infection should be considered as a prime target for phage therapy. In our few clinical cases we did not include chronic pulmonary infections in the absence of an inhalation administration methodology. But for the same reasons, such application should also be considered.

The positions of the medical community are contradictory for many reasons. One must admit that the use of such a biological rather than chemical drug is new and upsets conventional treatment regimens. Moreover, this development occurs in a more strictly regulated context than in the past, where therapeutic frameworks need to be reinvented. This requires reflection on how to refine treatment protocols by taking into account the interactions between bacteriophages and bacteria and to consider pharmacological measures [166] that will support clinical practice.

\section{7) Conflicts of interest}

The authors have no conflict of interest. 


\section{8) Literature cited}

1.d'Herelle, F. Sur un microbe invisible antagoniste des bacilles dysentériques. Compt. rend. Acad.

Sci. Paris 1917, 165, 373-375. [CrossRef], [PubMed]:

2.d'Herelle, F. Le bactériophage : son rôle dans l'immunité. Masson et Cie: Paris, 1921.

3.Bruynoghe, R.; Maisin, J. Essais de thérapeutique au moyen du bactériophage. C R Seances Soc Biol

Fil 1922, 85, 1120-1121. [CrossRef], [PubMed]:

4.WHO. Antimicrobial resistance: global report on surveillance 2014; 9789241564748 Organisation

Mondiale de la Santé: avril 2014, 2014; p 257.

5.Wittebole, X.; De Roock, S.; Opal, S.M. A historical overview of bacteriophage therapy as an

alternative to antibiotics for the treatment of bacterial pathogens. Virulence 2013, 4, 1-10.

[CrossRef], [PubMed]: http://www.ncbi.nlm.nih.gov/pubmed/23973944

6.Pires, D.P.; Melo, L.; Vilas Boas, D.; Sillankorva, S.; Azeredo, J. Phage therapy as an alternative or complementary strategy to prevent and control biofilm-related infections. Curr Opin Microbiol 2017, 39, 48-56. [CrossRef]: http://doi.org/10.1016/j.mib.2017.09.004, [PubMed]:

https://www.ncbi.nlm.nih.gov/pubmed/28964986

7.Pirnay, J.-P.; Verbeken, G.; Ceyssens, P.-J.; Huys, I.; De Vos, D.; Ameloot, C.; Fauconnier, A. The magistral phage. Viruses 2018, 10, 64. [CrossRef]: http://doi.org/10.3390/v10020064, [PubMed]: http://www.mdpi.com/1999-4915/10/2/64

8.Verbeken, G.; Pirnay, J.P.; Lavigne, R.; Jennes, S.; De Vos, D.; Casteels, M.; Huys, I. Call for a dedicated european legal framework for bacteriophage therapy. Arch Immunol Ther Exp (Warsz) 2014, 62, 117-129. [CrossRef]: http://doi.org/10.1007/s00005-014-0269-y, [PubMed]: http://www.ncbi.nlm.nih.gov/pubmed/24500660

9.Pirnay, J.P.; Merabishvili, M.; Van Raemdonck, H.; De Vos, D.; Verbeken, G. Bacteriophage production in compliance with regulatory requirements. In Bacteriophage therapy : from lab to clinical practice, Azeredo, J.; Sillankorva, S., Eds. Humana Press: New York, 2018; Chap. 18, pp. 233-252; 1940-6029 (Electronic); 1064-3745 (Linking).

10.Salmond, G.P.; Fineran, P.C. A century of the phage: past, present and future. Nat. Rev. Microbiol. 2015, 13, 777-786. [CrossRef]: http://doi.org/10.1038/nrmicro3564, [PubMed]:

https://www.ncbi.nlm.nih.gov/pubmed/26548913

11.Ofir, G.; Sorek, R. Contemporary phage biology: from classic models to new insights. Cell 2018, 172, 1260-1270. [CrossRef]: http://doi.org/10.1016/j.cell.2017.10.045, [PubMed]: http://dx.doi.org/10.1016/j.cell.2017.10.045

12.Abedon, S.T.; Garcia, P.; Mullany, P.; Aminov, R. Editorial: phage therapy: Past, present and future. Front Microbiol 2017, 8, 981. [CrossRef]: http://doi.org/10.3389/fmicb.2017.00981, [PubMed]: https://www.ncbi.nlm.nih.gov/pubmed/28663740

13. Himmelweit, F. Combined action of penicillin and bacteriophage on staphylococci. Lancet $\mathbf{1 9 4 5 ,}$ 246, 104-105. [CrossRef], [PubMed]:

14.MacNeal, W.J.; Filak, L.; Blevins, A. Conjoined action of penicillin and bacteriophages. J. Lab. Clin. Med. 1946, 31, 974-981. [CrossRef], [PubMed]:

15.Adebayo, O.S.; Gabriel- Ajobiewe, R.; Taiwo, M.O.; Kayode, J.S. Phage therapy: A potential alternative in the treatment of multi-drug resistant bacterial infections. J Microbiol Exp 2017, 5. [CrossRef]: http://doi.org/10.15406/jmen.2017.05.00173, [PubMed]:

16.Torres-Barcelo, C.; Arias-Sánchez, F.I.; Vasse, M.; Ramsayer, J.; Kaltz, O.; Hochberg, M.E. A window of opportunity to control the bacterial pathogen Pseudomonas aeruginosa combining antibiotics and phages. PLOS ONE 2014, 9, e106628. [CrossRef]:

http://doi.org/10.1371/journal.pone.0106628, [PubMed]:

http://www.ncbi.nlm.nih.gov/pubmed/25259735

17.Torres-Barcelo, C.; Hochberg, M.E. Evolutionary rationale for phages as complements of antibiotics. Trends Microbiol. 2016, 24, 249-256. [CrossRef]: http://doi.org/http://dx.doi.org/10.1016/j.tim.2015.12.011, [PubMed]:

http://www.ncbi.nlm.nih.gov/pubmed/26786863

18.Mion, S.; Remy, B.; Plener, L.; Chabriere, E.; Daude, D. Empécher les bacteries de communiquer : diviser pour mieux soigner. Ann Pharm Fr 2018. [CrossRef]: 
http://doi.org/10.1016/j.pharma.2018.02.004, [PubMed]:

https://www.ncbi.nlm.nih.gov/pubmed/29598881

19.Chan, B.K.; Turner, P.E.; Kim, S.; Mojibian, H.R.; Elefteriades, J.A.; Narayan, D. Phage treatment of an aortic graft infected with Pseudomonas aeruginosa. Evol Med Public Health 2018, 2018, 60-66. [CrossRef]: http://doi.org/10.1093/emph/eoy005, [PubMed]:

https://www.ncbi.nlm.nih.gov/pubmed/29588855

20.Stratton, C.W. Phages, fitness, virulence, and synergy: A novel approach for the therapy of infections caused by Pseudomonas aeruginosa. J Infect Dis 2016. [CrossRef]:

http://doi.org/10.1093/infdis/jiw634, [PubMed]: https://www.ncbi.nlm.nih.gov/pubmed/28007923

21.Oechslin, F.; Piccardi, P.; Mancini, S.; Gabard, J.; Moreillon, P.; Entenza, J.M.; Resch, G.; Que,

Y.A. Synergistic interaction between phage therapy and antibiotics clears Pseudomonas aeruginosa infection in endocarditis and reduces virulence. J Infect Dis 2016. [CrossRef]:

http://doi.org/10.1093/infdis/jiw632, [PubMed]: https://www.ncbi.nlm.nih.gov/pubmed/28007922

22.Edgar, R.; Friedman, N.; Molshanski-Mor, S.; Qimron, U. Reversing bacterial resistance to antibiotics by phage-mediated delivery of dominant sensitive genes. Appl. Environ. Microbiol. 2012, 78, 744-751. [CrossRef]: http://doi.org/10.1128/AEM.05741-11, [PubMed]:

http://www.ncbi.nlm.nih.gov/pubmed/22113912

23.Regeimbal, J.M.; Jacobs, A.C.; Corey, B.W.; Henry, M.S.; Thompson, M.G.; Pavlicek, R.L.; Quinones, J.; Hannah, R.M.; Ghebremedhin, M.; Crane, N.J., et al. Personalized therapeutic cocktail of wild environmental phages rescues mice from $A$. baumannii wound infections. Antimicrob. Agents Chemother. 2016, 60, 5806-5816. [CrossRef]: http://doi.org/10.1128/AAC.02877-15, [PubMed]: http://www.ncbi.nlm.nih.gov/pubmed/27431214 24.Abedon, S.T. Bacteriophages and Biofilms: Ecology, Phage Therapy, Plaques. In Biofilms: Formation, Development and Properties, William C. Bailey, Ed. Nova Science Publishers: Hauppauge, New York, 2011; Chap. pp. 1-58; ISBN-10: 1617282936

ISBN-13: 9781617282935.

25.Kumaran, D.; Taha, M.; Yi, Q.; Ramirez-Arcos, S.; Diallo, J.S.; Carli, A.; Abdelbary, H. Does treatment order matter? Investigating the ability of bacteriophage to augment antibiotic activity against Staphylococcus aureus biofilms. Front Microbiol 2018, 9, 127. [CrossRef]: http://doi.org/10.3389/fmicb.2018.00127, [PubMed]:

https://www.ncbi.nlm.nih.gov/pubmed/29459853

26.Sanchez, C.J., Jr.; Ward, C.L.; Romano, D.R.; Hurtgen, B.J.; Hardy, S.K.; Woodbury, R.L.; Trevino, A.V.; Rathbone, C.R.; Wenke, J.C. Staphylococcus aureus biofilms decrease osteoblast viability, inhibits osteogenic differentiation, and increases bone resorption in vitro. BMC musculoskeletal disorders 2013, 14, 187-198. [CrossRef]: http://doi.org/10.1186/1471-2474-14-187, [PubMed]: http://www.ncbi.nlm.nih.gov/pubmed/23767824

27.Samson, J.E.; Magadan, A.H.; Sabri, M.; Moineau, S. Revenge of the phages: defeating bacterial defences. Nature Reviews Microbiology 2013, 11, 675-687. [CrossRef]:

http://doi.org/10.1038/nrmicro3096, [PubMed]: http://www.ncbi.nlm.nih.gov/pubmed/23979432

28.Letarov, A.V.; Golomidova, A.K.; Tarasyan, K.K. Ecological basis for rational phage therapy. Acta

Naturae 2010, 2, 60-72. [CrossRef], [PubMed]: http://www.ncbi.nlm.nih.gov/pubmed/22649629

29.Maisin, J. Adaptation du bactériophage. C R Seances Soc Biol Fil 1921, 84, 468-470. [CrossRef], [PubMed]:

30.d'Herelle, F. The nature of the bacteriophage. Br. Med. J. 1922, 2, 289-293. [CrossRef], [PubMed]:

31.Betts, A.; Kaltz, O.; Hochberg, M.E. Contrasted coevolutionary dynamics between a bacterial pathogen and its bacteriophages. Proc Natl Acad Sci U S A 2014, 111, 11109-11114. [CrossRef]: http://doi.org/10.1073/pnas.1406763111, [PubMed]: http://www.ncbi.nlm.nih.gov/pubmed/25024215 32.Vieu, J.-F.; Guillermet, F.; Minck, R.; Nicolle, P. Données actuelles sur les applications thérapeutiques des bactériophages. Bul. Acad. Nat. Méd. 1979, 1, 61-66. [CrossRef], [PubMed]: 33.Khalifa, L.; Gelman, D.; Shlezinger, M.; Dessal, A.L.; Coppenhagen-Glazer, S.; Beyth, N.; Hazan, R. Defeating antibiotic- and phage-resistant Enterococcus faecalis using a phage cocktail in vitro and in a clot model. Front Microbiol 2018, 9. [CrossRef]: http://doi.org/10.3389/fmicb.2018.00326, [PubMed]: https://www.ncbi.nlm.nih.gov/pubmed/29541067 
34.Yu, L.; Wang, S.; Guo, Z.; Liu, H.; Sun, D.; Yan, G.; Hu, D.; Du, C.; Feng, X.; Han, W., et al. A guard-killer phage cocktail effectively lyses the host and inhibits the development of phage-resistant strains of Escherichia coli. Appl Microbiol Biotechnol 2018, 102, 971-983. [CrossRef]: http://doi.org/10.1007/s00253-017-8591-z, [PubMed]:

https://www.ncbi.nlm.nih.gov/pubmed/29150707

35.Roach, D.R.; Leung, C.Y.; Henry, M.; Morello, E.; Singh, D.; Di Santo, J.P.; Weitz, J.S.;

Debarbieux, L. Synergy between the host immune system and bacteriophage is essential for successful phage therapy against an acute respiratory pathogen. Cell host \& microbe 2017, 22, 38-47 e34. [CrossRef]: http://doi.org/10.1016/j.chom.2017.06.018, [PubMed]:

https://www.ncbi.nlm.nih.gov/pubmed/28704651

36.Dabrowska, K.; Miedzybrodzki, R.; Miernikiewicz, P.; Figura, G.; Klak, M.; Górski, A. Nonbactericidal effects of phages in mammals. In Phage Therapy: Current Research and Applications, Borysowski, J.; Miedzybrodzki, R.; Gorski, A., Eds. Norfolk (England), 2014; Chap. 5, pp. 141-155; 37.Kazmierczak, Z.; Dabrowska, K. Interaction of bacteriophages with mammalian cells. In Bacteriophage therapy : from lab to clinical practice, Azeredo, J.; Sillankorva, S., Eds. Humana Press: New York, 2018; Chap. 10, pp. 113-122; 1940-6029 (Electronic); 1064-3745 (Linking).

38.Palmela, C.; Chevarin, C.; Xu, Z.; Torres, J.; Sevrin, G.; Hirten, R.; Barnich, N.; Ng, S.C.; Colombel, J.F. Adherent-invasive Escherichia coli in inflammatory bowel disease. Gut 2018, 67, 574-587. [CrossRef]: http://doi.org/10.1136/gutjnl-2017-314903, [PubMed]:

https://www.ncbi.nlm.nih.gov/pubmed/29141957

39.Tang, J. Microbiome in the urinary system-a review. 2017; Vol. 3, p 143-154.

40.Kuntz, T.M.; Gilbert, J.A. Introducing the microbiome into precision medicine. Trends Pharmacol. Sci. 2017, 38, 81-91. [CrossRef]: http://doi.org/10.1016/j.tips.2016.10.001, [PubMed]: http://dx.doi.org/10.1016/j.tips.2016.10.001

41.Kosyakovsky, L.B. The emerging role of the microbiome in precision medicine: An overview. UBCMJ 2017, 9, 10-12. [CrossRef], [PubMed]:

42.Sunderland, K.; Yang, M.; Mao, C. Phage-enabled nanomedicine: From probes to therapeutics in precision medicine. Angew Chem Int Ed Engl 2016. [CrossRef]:

http://doi.org/10.1002/anie.201606181, [PubMed]: http://www.ncbi.nlm.nih.gov/pubmed/27491926

43.Dabrowska, K. Interaction of bacteriophages with the immune system: Induction of bacteriophagespecific antibodies. In Bacteriophage therapy : from lab to clinical practice, Azeredo, J.; Sillankorva, S., Eds. Humana Press: New York, 2018; Chap. 12, pp. 139-150; 1940-6029 (Electronic); 1064-3745 (Linking).

44.Mirzaei, M.K.; Maurice, C.F. Menage a trois in the human gut: interactions between host, bacteria and phages. Nat. Rev. Microbiol. 2017, 15, 397-408. [CrossRef]:

http://doi.org/10.1038/nrmicro.2017.30, [PubMed]: https://www.ncbi.nlm.nih.gov/pubmed/28461690 45.Jonczyk-Matysiak, E.; Weber-Dabrowska, B.; Owczarek, B.; Miedzybrodzki, R.; Lusiak-

Szelachowska, M.; Lodej, N.; Gorski, A. Phage-phagocyte interactions and their implications for phage application as therapeutics. Viruses 2017, 9. [CrossRef]: http://doi.org/10.3390/v9060150, [PubMed]: https://www.ncbi.nlm.nih.gov/pubmed/28613272

46.Schommer, N.N.; Gallo, R.L. Structure and function of the human skin microbiome. Trends Microbiol. 2013, 21, 660-668. [CrossRef]: http://doi.org/10.1016/j.tim.2013.10.001, [PubMed]: http://www.ncbi.nlm.nih.gov/pubmed/24238601

47.Miller-Ensminger, T.; Garretto, A.; Brenner, J.; Thomas-White, K.; Zambom, A.; Wolfe, A.J.; Putonti, C. Bacteriophages of the urinary microbiome. J. Bacteriol. 2018. [CrossRef]:

http://doi.org/10.1128/JB.00738-17, [PubMed]: https://www.ncbi.nlm.nih.gov/pubmed/29378882 48.Krishnan, K.; Chen, T.; Paster, B.J. A practical guide to the oral microbiome and its relation to health and disease. Oral Dis 2017, 23, 276-286. [CrossRef]: http://doi.org/10.1111/odi.12509, [PubMed]: https://www.ncbi.nlm.nih.gov/pubmed/27219464

49.Bogdanos, D.P.; Smyk, D.; Shoenfeld, Y. The microbiome of the lung. The Israel Medical Association journal : IMAJ 2013, 15, 766-767. [CrossRef], [PubMed]:

http://www.ncbi.nlm.nih.gov/pubmed/24449982

50.Schooley, R.T.; Biswas, B.; Gill, J.J.; Hernandez-Morales, A.; Lancaster, J.; Lessor, L.; Barr, J.J.; Reed, S.L.; Rohwer, F.; Benler, S., et al. Development and use of personalized bacteriophage-based 
therapeutic cocktails to treat a patient with a disseminated resistant Acinetobacter baumannii infection. Antimicrob. Agents Chemother. 2017, 61. [CrossRef]: http://doi.org/10.1128/AAC.0095417, [PubMed]: https://www.ncbi.nlm.nih.gov/pubmed/28807909

51.Mattila, S.; Ruotsalainen, P.; Jalasvuori, M. On-demand isolation of bacteriophages against drugresistant bacteria for personalized phage therapy. Frontiers in Microbiology 2015, 6, 1271.

[CrossRef]: http://doi.org/10.3389/fmicb.2015.01271, [PubMed]: http://www.ncbi.nlm.nih.gov/pubmed/26617601

52.Sillankorva, S. Isolation of bacteriophages for clinically relevant bacteria. In Bacteriophage therapy : from lab to clinical practice, Humana Press ed.; Azeredo, J.; Sillankorva, S., Eds. Springer: New

York, 2018; Chap. 3, pp. 23-30; 1940-6029 (Electronic); 1064-3745 (Linking).

53.Euralex volume 4 - Good Manufacturing Practice (GMP) guidelines

https://ec.europa.eu/health/documents/eudralex/vol-4 en

54.Kutter, E.M.; Gvasalia, G.; Alavidze, Z.; Brewster, E. Phage Therapy. In Biotherapy - History, Principles and Practice, 2013; Chap. pp. 191-231;

55.Fauconnier, A. Guidelines for bacteriophage product certification. In Bacteriophage Therapy. Methods in Molecular Biology, Azeredo, J.; Sillankorva, S., Eds. Humana Press: New York, NY, 2018; Chap. 19, pp. 253-268; 1940-6029 (Electronic); 1064-3745 (Linking).

56.Pirnay, J.P.; De Vos, D.; Verbeken, G.; Merabishvili, M.; Vaneechoutte, M.; Zizi, M.; Laire, G.; Lavigne, R.; Huys, I.; Van den Mooter, G., et al. The Phage Therapy Paradigm: « Prêt à Porter » or « Sur-mesure »? Pharm. Res. 2011, 28, 934-937. [CrossRef], [PubMed]:

57.Jassim, S.A.; Limoges, R.G. Natural solution to antibiotic resistance: bacteriophages 'The Living Drugs'. World. J. Microbiol. Biotechnol. 2014. [CrossRef]: http://doi.org/10.1007/s11274-014-16557, [PubMed]: http://www.ncbi.nlm.nih.gov/pubmed/24781265

58.Zhukov-Verezhnikov, N.N.; Peremitina, L.D.; Berillo, E.A.; Komissarov, V.P.; Bardymov, V.M.; Khvoles, A.G.; Ugryumov, L.B. A study of the therapeutic effect of bacteriophage agents in a complex treatment of suppurative surgical diseases. Sov. Med. 1978, 12, 64-66. [CrossRef], [PubMed]:

59.Sulakvelidze, A.; Alavidze, Z.; Morris, J.G. Bacteriophage therapy. Antimicrob. Agents

Chemother. 2001, 45, 649-659. [CrossRef], [PubMed]:

60.Casey, E.; van Sinderen, D.; Mahony, J. In vitro characteristics of phages to guide 'real life' phage therapy suitability. Viruses 2018, 10. [CrossRef]: http://doi.org/10.3390/v10040163, [PubMed]: https://www.ncbi.nlm.nih.gov/pubmed/29601536

61.Skurnik, M.; Pajunen, M.; Kiljunen, S. Biotechnological challenges of phage therapy. Biotechnol. Lett. 2007, 29, 995-1003. [CrossRef]: http://doi.org/10.1007/s10529-007-9346-1, [PubMed]: http://www.ncbi.nlm.nih.gov/pubmed/17364214

62.Leung, S.S.; Parumasivam, T.; Gao, F.G.; Carrigy, N.B.; Vehring, R.; Finlay, W.H.; Morales, S.; Britton, W.J.; Kutter, E.; Chan, H.K. Effects of storage conditions on the stability of spray dried, inhalable bacteriophage powders. Int J Pharm 2017, 521, 141-149. [CrossRef]:

http://doi.org/10.1016/j.ijpharm.2017.01.060, [PubMed]:

https://www.ncbi.nlm.nih.gov/pubmed/28163231

63.Brown, T.L.; Petrovski, S.; Chan, H.T.; Angove, M.J.; Tucci, J. Semi-solid and solid dosage forms for the delivery of phage therapy to epithelia. Pharmaceuticals 2018, 11. [CrossRef]:

http://doi.org/10.3390/ph11010026, [PubMed]: https://www.ncbi.nlm.nih.gov/pubmed/29495355

64.Vandenheuvel, D.; Singh, A.; Vandersteegen, K.; Klumpp, J.; Lavigne, R.; Van den Mooter, G.

Feasibility of spray drying bacteriophages into respirable powders to combat pulmonary bacterial infections. Eur. J. Pharm. Biopharm. 2013, 84, 578-582. [CrossRef]:

http://doi.org/10.1016/j.ejpb.2012.12.022, [PubMed]:

http://www.ncbi.nlm.nih.gov/pubmed/23353012

65.Matinkhoo, S.; Lynch, K.H.; Dennis, J.J.; Finlay, W.H.; Vehring, R. Spray-dried respirable powders containing bacteriophages for the treatment of pulmonary infections. J Pharm Sci 2011, 100, 5197-5205. [CrossRef]: http://doi.org/10.1002/jps.22715, [PubMed]:

http://www.ncbi.nlm.nih.gov/pubmed/22020816

66.Smith, W.D.; Bardin, E.; Cameron, L.; Edmondson, C.L.; Farrant, K.V.; Martin, I.; Murphy, R.A.; Soren, O.; Turnbull, A.R.; Wierre-Gore, N., et al. Current and future therapies for Pseudomonas 
aeruginosa infection in patients with cystic fibrosis. FEMS Microbiol. Lett. 2017, 364. [CrossRef]: http://doi.org/10.1093/femsle/fnx121, [PubMed]: https://www.ncbi.nlm.nih.gov/pubmed/28854668 67.Dufour, N.; Delattre, R.; Ricard, J.-D.; Debarbieux, L. The lysis of pathogenic Escherichia coli by bacteriophages releases less endotoxin than betalactams. Clinical Infectious Diseases 2017, 64, 15821588. [CrossRef]: http://doi.org/10.1093/cid/cix184, [PubMed]:

https://www.ncbi.nlm.nih.gov/pubmed/28329379

68.Parracho, H.M.; Burrowes, B.H.; Enright, M.C.; McConville, M.L.; Harper, D.R. The role of regulated clinical trials in the development of bacteriophage therapeutics. Journal of Molecular and Genetic Medicine 2012, 6, 279-286. [CrossRef], [PubMed]:

http://www.ncbi.nlm.nih.gov/pubmed/22872803

69.Chanishvili, N. A literature review of the practical application of bacteriophage research. Nova Science Publishers: New York, 2012.

70.Slopek, S.; Kucharewicz-Krukowska, A.; Weber-Dabrowska, B.; Dabrowski, M. Results of bacteriophage treatment of suppurative bacterial infections. IV. Evaluation of results obtained in 370 cases. Archivum Immunologii et Therapiae Experimentalis 1985, 33, 219-240. [CrossRef], [PubMed]:

71.Imbert, L. Le chirurgien André RAIGA-CLEMENCEAU (1893 - 1979). Sa vie et son œuvre consacrées à la phagothérapie. Besançon, Besançon, 2014.

72.Raiga, A. La phagothérapie pré-opératoire. Guérison des ostéites fistulisées. Résultats éloignés de 10 et 11 ans. Bull Mem Soc Chir Paris 1953, 43, 164. [CrossRef], [PubMed]:

73.Sarker, S.A.; Berger, B.; Deng, Y.; Kieser, S.; Foata, F.; Moine, D.; Descombes, P.; Sultana, S.; Huq, S.; Bardhan, P.K., et al. Oral application of Escherichia coli bacteriophage: safety tests in healthy and diarrheal children from Bangladesh. Environ Microbiol 2017, 19, 237-250. [CrossRef]: http://doi.org/10.1111/1462-2920.13574, [PubMed]:

https://www.ncbi.nlm.nih.gov/pubmed/27750388

74.McCallin, S.; Alam Sarker, S.; Barretto, C.; Sultana, S.; Berger, B.; Huq, S.; Krause, L.; Bibiloni, R.; Schmitt, B.; Reuteler, G., et al. Safety analysis of a Russian phage cocktail: From metagenomic analysis to oral application in healthy human subjects. Virology 2013, 443, 187-196. [CrossRef]: http://doi.org/10.1016/j.virol.2013.05.022, [PubMed]:

http://www.ncbi.nlm.nih.gov/pubmed/23755967

75.Maura, D.; Debarbieux, L. On the interactions between virulent bacteriophages and bacteria in the gut. Bacteriophage 2012, 2, 229-233. [CrossRef], [PubMed]:

76.Carding, S.R.; Davis, N.; Hoyles, L. Review article: the human intestinal virome in health and disease. Aliment. Pharmacol. Ther. 2017. [CrossRef]: http://doi.org/10.1111/apt.14280, [PubMed]: https://www.ncbi.nlm.nih.gov/pubmed/28869283

77.López, L.; Burgos, G.; Gálvez, A.; Pulido, P. The human gastrointestinal tract and oral microbiota in inflammatory bowel disease: a state of the science review. APMIS 2017, 125, 3-10. [CrossRef]: http://doi.org/doi: 10.1111/apm.12609, [PubMed]: https://www.ncbi.nlm.nih.gov/pubmed/27704622 78.Galtier, M.; De Sordi, L.; Sivignon, A.; de Vallee, A.; Maura, D.; Neut, C.; Rahmouni, O.; Wannerberger, K.; Darfeuille-Michaud, A.; Desreumaux, P., et al. Bacteriophages targeting adherent invasive Escherichia coli strains as a promising new treatment for crohn's disease. J Crohns Colitis 2017, 11, 840-847. [CrossRef]: http://doi.org/10.1093/ecco-jcc/jjw224, [PubMed]: https://www.ncbi.nlm.nih.gov/pubmed/28130329

79.Shan, J.; Ramachandran, A.; Thanki, A.M.; Vukusic, F.B.I.; Barylski, J.; Clokie, M.R.J.

Bacteriophages are more virulent to bacteria with human cells than they are in bacterial culture; insights from HT-29 cells. Scientific reports 2018, 8, 5091. [CrossRef]:

http://doi.org/10.1038/s41598-018-23418-y, [PubMed]:

https://www.ncbi.nlm.nih.gov/pubmed/29572482

80.Nale, J.Y.; Redgwell, T.A.; Millard, A.; Clokie, M.R.J. Efficacy of an optimised bacteriophage cocktail to clear Clostridium difficile in a batch fermentation model. Antibiotics (Basel) 2018, 7. [CrossRef]: http://doi.org/10.3390/antibiotics7010013, [PubMed]:

https://www.ncbi.nlm.nih.gov/pubmed/29438355

81.Moelling, K.; Broecker, F. Fecal microbiota transplantation to fight Clostridium difficile infections and other intestinal diseases. Bacteriophage 2016, 6, e1251380. [CrossRef]: 
http://doi.org/10.1080/21597081.2016.1251380, [PubMed]:

https://www.ncbi.nlm.nih.gov/pubmed/28090385

82.Zuo, T.; Wong, S.H.; Lam, K.; Lui, R.; Cheung, K.; Tang, W.; Ching, J.Y.L.; Chan, P.K.S.; Chan, M.C.W.; Wu, J.C.Y., et al. Bacteriophage transfer during faecal microbiota transplantation in Clostridium difficile infection is associated with treatment outcome. Gut 2018, 67, 634-643.

[CrossRef]: http://doi.org/10.1136/gutjnl-2017-313952, [PubMed]:

https://www.ncbi.nlm.nih.gov/pubmed/28539351

83.Jonczyk-Matysiak, E.; Weber-Dabrowska, B.; Zaczek, M.; Miedzybrodzki, R.; Letkiewicz, S.; Lusiak-Szelchowska, M.; Gorski, A. Prospects of phage application in the treatment of acne caused by propionibacterium acnes. Front Microbiol 2017, 8, 164. [CrossRef]:

http://doi.org/10.3389/fmicb.2017.00164, [PubMed]:

https://www.ncbi.nlm.nih.gov/pubmed/28228751

84.Mihu, M.R.; Martinez, L.R. Novel therapies for treatment of multi-drug resistant Acinetobacter baumannii skin infections. Virulence 2011, 2, 97-102. [CrossRef], [PubMed]:

http://www.ncbi.nlm.nih.gov/pubmed/21321482

85.Le Floch, R.; Naux, E.; Arnould, J.F. L'infection bactérienne chez le brûlé. Annals of Burns and

Fire Disasters 2015, 18, 94-104. [CrossRef], [PubMed]:

86.Rose, T.; Verbeken, G.; De Vos, D.; Merabishvili, M.; Vaneechoutte, M.; Lavigne, R.; Jennes, S.; Zizi, M.; Pirnay, J.P. Experimental phage therapy of burn wound infection: difficult first steps.

International journal of burns and trauma 2014, 4, 66-73. [CrossRef], [PubMed]:

http://www.ncbi.nlm.nih.gov/pubmed/25356373

87.Servick, K. DRUG DEVELOPMENT. Beleaguered phage therapy trial presses on. Science 2016, 352, 1506. [CrossRef]: http://doi.org/10.1126/science.352.6293.1506, [PubMed]:

http://www.ncbi.nlm.nih.gov/pubmed/27339963

88.PhagoBurn : http://www.phagoburn.eu/

89.Zhvania, P.; Hoyle, N.S.; Nadareishvili, L.; Nizharadze, D.; Kutateladze, M. Phage therapy in a 16year-old boy with Netherton syndrome. Front Med (Lausanne) 2017, 4, 94. [CrossRef]:

http://doi.org/10.3389/fmed.2017.00094, [PubMed]:

https://www.ncbi.nlm.nih.gov/pubmed/28717637

90.Garcia-Aljaro, C.; Muniesa, M.; Jofre, J. Isolation of bacteriophages of the anaerobic bacteria

Bacteroides. In Bacteriophage therapy : from lab to clinical practice, Springer New York ed.;

Azeredo, J.; Sillankorva, S., Eds. Humana Press: New York, 2018; Chap. 2, pp. 11-22; 1940-6029

(Electronic); 1064-3745 (Linking).

91.Qasim, S.N.; Swann, A.; Ashford, R. The DAIR (debridement, antibiotics and implant retention) procedure for infected total knee replacement - a literature review. SICOT J 2017, 3, 2. [CrossRef]: http://doi.org/10.1051/sicotj/2016038, [PubMed]: https://www.ncbi.nlm.nih.gov/pubmed/28074774 92.Seth, A.K.; Geringer, M.R.; Nguyen, K.T.; Agnew, S.P.; Dumanian, Z.; Galiano, R.D.; Leung, K.P.; Mustoe, T.A.; Hong, S.J. Bacteriophage therapy for Staphylococcus aureus biofilm-infected wounds: a new approach to chronic wound care. Plastic and reconstructive surgery 2013, 131, 225234. [CrossRef]: http://doi.org/10.1097/PRS.0b013e31827e47cd, [PubMed]:

http://www.ncbi.nlm.nih.gov/pubmed/23357984

93.Wildeman, P.; Brüggemann, H.; Scholz, C.F.P.; Leimbach, A.; Söderquist, B. Propionibacterium avidum as an etiological agent of prosthetic hip joint infection. PlosOne 2016. [CrossRef], [PubMed]: 94.Kremers, H.M.; Nwojo, M.E.; Ransom, J.E.; Wood-Wentz, C.M.; Melton, L.J., 3rd; Huddleston, P.M., 3rd. Trends in the epidemiology of osteomyelitis: a population-based study, 1969 to 2009. The Journal of bone and joint surgery 2015, 97, 837-845. [CrossRef]:

http://doi.org/10.2106/JBJS.N.01350, [PubMed]: http://www.ncbi.nlm.nih.gov/pubmed/25995495 95.Grammatico-Guillon, L.; Baron, S.; Gettner, S.; Lecuyer, A.-I.; Gaborit, C.; Rosset, P.; Rusch, E.; Bernard, L. Surveillance hospitalière des infections ostéo-articulaires en France : analyse des données médico-administratives, PMSI 2008. B. E. H. 2013, 39-44. [CrossRef], [PubMed]:

96.Albee, F.H. The treatment of osteomyelitis by bacteriophage. The Journal of bone and joint surgery 1933, 15, 58-66. [CrossRef], [PubMed]: 
97.Slopek, S.; Weber Dabrowska, B.; Dabrowski, M.; Kucharewicz-Krukowska, A. Results of bacteriophage treatment of suppurative bacterial infections in the years 1981-1986. Archivum Immunologiae et Therapiae Experimentalis 1987, 37, 369-383. [CrossRef], [PubMed]:

98.Chanishvili, N. Experience of the Eliava Institute of Bacteriophage, Microbiology and Virology in development of the innovative bio-preparations and their commercialization. 2011.

99.Raiga, A. In Considérations générales sur l'ostéomyélite aiguë et son traitement par le bactériophage de d'Hérelle, 52 ème Congrès Francais de Chirurgie, Paris, 1949/10/04, 1949; Paris. 100.Lang, G.; Kher, P.; Mathevon, H.; Clavert, J.M.; Séjourne, P.; Pointu, J. Bactériophages et chirurgie orthopédique - A propos de sept cas. Rev. Chir. Orthop. Reparatrice Appar. Mot. 1979, 65, 33-37. [CrossRef], [PubMed]:

101.Yilmaz, C.; Colak, M.; Yilmaz, B.C.; Ersoz, G.; Kutateladze, M.; Gozlugol, M. Bacteriophage therapy in implant-related infections: an experimental study. The Journal of bone and joint surgery 2013, 95, 117-125. [CrossRef]: http://doi.org/10.2106/JBJS.K.01135, [PubMed]: http://www.ncbi.nlm.nih.gov/pubmed/23324958

102.VinodKumar, C.S.; Srinivasa, H.; K.G, B.; Patil, U.; Bandekar, N.; Patil, R. Abrogation of Staphylococcus aureus Wound Infection by Bacteriophage in Diabetic Rats. International Journal of Pharmaceutical Sciences and Drug Research 2011, 3, 202-207. [CrossRef], [PubMed]:

103.Chhibber, S.; Kaur, T.; Sandeep, K. Co-therapy using lytic bacteriophage and linezolid: effective treatment in eliminating methicillin resistant staphylococcus aureus (mrsa) from diabetic foot infections. PLOS ONE 2013, 8, e56022. [CrossRef]: http://doi.org/10.1371/journal.pone.0056022, [PubMed]: http://www.ncbi.nlm.nih.gov/pubmed/23418497

104.Akanda, Z.Z.; Taha, M.; Abdelbary, H. Current review - The rise of bacteriophage as a unique therapeutic platform in treating peri-prosthetic joint infections. J. Orthop. Res. 2017. [CrossRef]: http://doi.org/10.1002/jor.23755, [PubMed]: https://www.ncbi.nlm.nih.gov/pubmed/28971508 105.Kishor, C.; Mishra, R.R.; Saraf, S.K.; Kumar, M.; Srivastav, A.K.; Nath, G. Phage therapy of staphylococcal chronic osteomyelitis in experimental animal model. The Indian Journal of Medical Research 2016, 143, 87-94. [CrossRef]: http://doi.org/10.4103/0971-5916.178615, [PubMed]: http://www.ncbi.nlm.nih.gov/pubmed/26997019

106.Kaur, S.; Harjai, K.; Chhibber, S. In vivo assessment of phage and linezolid based implant coatings for treatment of methicillin resistant $S$. aureus (MRSA) mediated orthopaedic device related infections. PLOS ONE 2016, 11, e0157626. [CrossRef]: http://doi.org/10.1371/journal.pone.0157626, [PubMed]: http://www.ncbi.nlm.nih.gov/pubmed/27333300

107.Pherecydes Pharma : http://fr.pherecydes-pharma.com/

108.Morozova, V.V.; Kozlova, Y.N.; Ganichev, D.A.; Tikunova, N.V. Bacteriophage treatment of infected diabetic foot ulcers. In Bacteriophage therapy : from lab to clinical practice, Azeredo, J.; Sillankorva, S., Eds. Humana Press: Springer New York, 2018; Chap. 13, pp. 151-158; 1940-6029 (Electronic); 1064-3745 (Linking).

109.Fish, R.; Kutter, E.; Wheat, G.; Blasdel, B.; Kutateladze, M.; Kuhl, S. Bacteriophage treatment of intransigent diabetic toe ulcers: a case series. J. Wound Care 2016, 25 Suppl 7, S27-33. [CrossRef]: http://doi.org/10.12968/jowc.2016.25.7.S27, [PubMed]:

http://www.ncbi.nlm.nih.gov/pubmed/27410468

110.Beckerich, A.; Hauduroy, P. Le traitement des infections urinaires à colibacilles par le bactériophage de d'Hérelle. Bulletin médical 1923, 37, 273. [CrossRef], [PubMed]:

111.Schultz, E.W. Bacteriophage as a therapeutic agent in genito-urinary infections: Part 1. Cal. West. Med. 1932, 36, 33-37. [CrossRef], [PubMed]:

112.Schultz, E.W. Bacteriophage as a Therapeutic Agent in Genito-Urinary Infections: Part II. Cal. West. Med. 1932, 36, 91-96. [CrossRef], [PubMed]:

113.Wehrbein, H.L.; Nerb, L. Bacteriophage in the treatment of urinary infections. With an appendix on the technique of phage preparation. Am. J. Surg. 1935, 29, 48-53. [CrossRef], [PubMed]:

114.Ujmajuridze, A.; Jvania, G.; Chanishvili, N.; Goderdzishvili, M.; Sybesma, W.; Managadze, L.; Chkhotua, A.; Kessler, T. Phage therapy for the treatment for urinary tract infection: Results of invitro screenings and in-vivo application using commercially available bacteriophage cocktails. European Urology Supplements 2016, 15, e265. [CrossRef], [PubMed]: 
115.Sybesma, W.; Zbinden, R.; Chanishvili, N.; Kutateladze, M.; Chkhotua, A.; Ujmajuridze, A.; Mehnert, U.; Kessler, T.M. Bacteriophages as potential treatment for urinary tract infections. Frontiers in Microbiology 2016, 7, 465. [CrossRef]: http://doi.org/10.3389/fmicb.2016.00465, [PubMed]: http://www.ncbi.nlm.nih.gov/pubmed/27148173

116.Khawaldeh, A.; Morales, S.; Dillon, B.; Alavidze, Z.; Ginn, A.N.; Thomas, L.; Chapman, S.J.; Dublanchet, A.; Smithyman, A.; Iredell, J.R. Bacteriophage therapy for refractory Pseudomonas aeruginosa urinary tract infection. Journal of Medical Microbiology 2011, 60, 1697-1700.

[CrossRef]: http://doi.org/10.1099/jmm.0.029744-0, [PubMed]:

http://www.ncbi.nlm.nih.gov/pubmed/21737541

117.Melo, L.D.; Veiga, P.; Cerca, N.; Kropinski, A.M.; Almeida, C.; Azeredo, J.; Sillankorva, S. Development of a phage cocktail to control Proteus mirabilis catheter-associated urinary tract infections. Frontiers in Microbiology 2016, 7, 1024. [CrossRef]:

http://doi.org/10.3389/fmicb.2016.01024, [PubMed]: http://www.ncbi.nlm.nih.gov/pubmed/27446059

118.Nzakizwanayo, J.; Hanin, A.; Alves, D.R.; McCutcheon, B.; Dedi, C.; Salvage, J.; Knox, K.; Stewart, B.; Metcalfe, A.; Clark, J., et al. Bacteriophage can prevent encrustation and blockage of urinary catheters by Proteus mirabilis. Antimicrob. Agents Chemother. 2015, 60, 1530-1536.

[CrossRef]: http://doi.org/10.1128/AAC.02685-15, [PubMed]:

http://www.ncbi.nlm.nih.gov/pubmed/26711744

119.Letkiewicz, S.; Miedzybrodzki, R.; Fortuna, W.; Weber-Dabrowska, B.; Gorski, A. Eradication of Enterococcus faecalis by phage therapy in chronic bacterial prostatitis--case report. Folia Microbiologica 2009, 54, 457-461. [CrossRef]: http://doi.org/10.1007/s12223-009-0064-z, [PubMed]: http://www.ncbi.nlm.nih.gov/entrez/query.fcgi? $\mathrm{cmd}=$ Retrieve $\& \mathrm{db}=\mathrm{PubMed} \& \mathrm{dopt}=\mathrm{Citation} \&$ list uid $\underline{\mathrm{s}=19937220}$

120.Letkiewicz, S.; Miedzybrodzki, R.; Klak, M.; Jonczyk, E.; Weber-Dabrowska, B.; Gorski, A. The perspectives of the application of phage therapy in chronic bacterial prostatitis. FEMS Immunol. Med. Microbiol. 2010, 60, 99-112. [CrossRef]: http://doi.org/10.1111/j.1574-695X.2010.00723.x, [PubMed]: http://www.ncbi.nlm.nih.gov/pubmed/20698884

121.Leitner, L.; Sybesma, W.; Chanishvili, N.; Goderdzishvili, M.; Chkhotua, A.; Ujmajuridze, A.; Schneider, M.P.; Sartori, A.; Mehnert, U.; Bachmann, L.M., et al. Bacteriophages for treating urinary tract infections in patients undergoing transurethral resection of the prostate: a randomized, placebocontrolled, double-blind clinical trial. BMC Urol 2017, 17, 90. [CrossRef]:

http://doi.org/10.1186/s12894-017-0283-6, [PubMed]:

https://www.ncbi.nlm.nih.gov/pubmed/28950849

122.Morello, E.; Saussereau, E.; Maura, D.; Huerre, M.; Touqui, L.; Debarbieux, L. Pulmonary bacteriophage therapy on Pseudomonas aeruginosa cystic fibrosis strains: first steps towards treatment and prevention. PLOS ONE 2011, 6, e16963. [CrossRef]:

http://doi.org/10.1371/journal.pone.0016963, [PubMed]:

http://www.ncbi.nlm.nih.gov/pubmed/21347240

123.Abedon, S.T. Phage therapy of pulmonary infections. Bacteriophage 2015, 5, e1020260.

[CrossRef]: http://doi.org/10.1080/21597081.2015.1020260, [PubMed]:

http://www.ncbi.nlm.nih.gov/pubmed/26442188

124.Duez, J.-M.; Dupret-Louzeau, A.-M.; Neuwirth, C. Case report od phagetherapy of a P. aeruginosa pulmonary infected parient. 2007. [CrossRef], [PubMed]:

125.Kvachadze, L.; Balarjishvili, N.; Meskhi, T.; Tevdoradze, E.; Skhirtladze, N.; Pataridze, T.; Adamia, R.; Topuria, T.; Kutter, E.; Rohde, C., et al. Evaluation of lytic activity of staphylococcal bacteriophage Sb-1 against freshly isolated clinical pathogens. Microb. Biotechnol. 2011, 4, 643-650. [CrossRef]: http://doi.org/10.1111/j.1751-7915.2011.00259.x, [PubMed]:

http://www.ncbi.nlm.nih.gov/pubmed/21481199

126.http://fr.pherecydes-pharma.com/projet-recherche-pneumophage.html

127.Bodier-Montagutelli, E.; Morello, E.; l'Hostis, G.; Guillon, A.; Dalloneau, E.; Respaud, R.;

Pallaoro, N.; Blois, H.; Vecellio, L.; Gabard, J., et al. Inhaled phage therapy: a promising and challenging approach to treat bacterial respiratory infections. Expert Opin Drug Deliv 2016.

[CrossRef]: http://doi.org/10.1080/17425247.2017.1252329, [PubMed]:

https://www.ncbi.nlm.nih.gov/pubmed/27776446 
128.Merril, C.R.; Biswas, B.; Carlton, R.; Jensen, N.C.; Creed, G.J.; Zullo, S.; Adhya, S. Longcirculating bacteriophage as antibacterial agents. Proc Natl Acad Sci U S A 1996, 93, 3188-3192. [CrossRef], [PubMed]:

129.Schless, R.A. Staphylococcus aureus meningitis: treatment with specific bacteriophage. Am. J. Dis. Child. 1932, 44, 813-822. [CrossRef], [PubMed]:

130.MacNeal, W.J.; Frisbee, F.C.; Blevins, A. Recoveries of staphylococcic meningitis following bacteriophage therapy. Archives of Otolaryngology 1943, 37, 507-525. [CrossRef], [PubMed]: 131.Martin, $P$. Méningite posttraumatique à pyocyaniques traitée par un bactériophage adapté intrarachidien. Acta Chir. Belg. 1959, 58, 85-90. [CrossRef], [PubMed]:

132.Sedallian, P.; Bertoye, A.; Gauthier, J.; Muller, M.; Courtieu, A.L. Méningite purulente à colibacilles traitée par un bactériophage adapté intrarachidien. Lyon Médical 1958, 509-512. [CrossRef], [PubMed]:

133.Stroj, L.; Weber-Dabrowska, B.; Partyka, K.; Mulczyk, M.; Wojcik, M. [Successful treatment with bacteriophage in purulent cerebrospinal meningitis in a newborn]. Neurol Neurochir Pol 1999, 33, 693-698. [CrossRef], [PubMed]: http://www.ncbi.nlm.nih.gov/pubmed/10540729

134.Raiga, A. Septicémie à staphylocoqie guérie par une inoculation intra-veineuse de bactériophage.

Bulletin et Mémoire de la Société des Chirurgiens de Paris 1931, 23. [CrossRef], [PubMed]:

135.MacNeal, W.J. The use of bacteriophages in wound infection and in bacteremias. Am. J. Med. Sci.

1932, 184, 805. [CrossRef], [PubMed]:

136.MacNeal, W.J.; Frisbee, F.C.; Blevins, A. Bacteriophage therapy of staphylococcic septic obstruction of cavernous sinus: II . Report of cases. Archives of Ophthalmology 1943, 29, 341-368. [CrossRef], [PubMed]:

137.Grimont, P.A.D.; Grimont, F.; Lacut, J.-Y.; Issanchou, A.-M.; Aubertin, J. Traitement d'une endocardite à Serratia par les bactériophages (lettre). Nouvelle Presse Médicale 1978, 7, 2251.

[CrossRef], [PubMed]:

138.Duplessis, C.; Biswas, B.; Hanisch, B.; Perkins, M.; Henry, M.; Quinones, J.; Wolfe, D.; Estrella, L.; Hamilton, T. Refractory Pseudomonas bacteremia in a 2-Year-old sterilized by bacteriophage therapy. J Pediatric Infect Dis Soc 2017. [CrossRef]: http://doi.org/10.1093/jpids/pix056, [PubMed]: https://www.ncbi.nlm.nih.gov/pubmed/28992111

139.Speck, P.; Smithyman, A. Safety and efficacy of phage therapy via the intravenous route. FEMS Microbiol. Lett. 2016, 363. [CrossRef]: http://doi.org/10.1093/femsle/fnv242, [PubMed]: http://www.ncbi.nlm.nih.gov/pubmed/26691737

140.Wright, A.; Hawkins, C.H.; Anggard, E.E.; Harper, D.R. A controlled clinical trial of a therapeutic bacteriophage preparation in chronic otitis due to antibiotic-resistant Pseudomonas aeruginosa; a preliminary report of efficacy. Clinical otolaryngology and allied sciences 2009, 34, 349-357.

[CrossRef], [PubMed]:

141.Szaleniec, J.; Gorski, A.; Szaleniec, M.; Miedzybrodzki, R.; Weber-Dabrowska, B.; Strek, P.; Skladzien, J. Can phage therapy solve the problem of recalcitrant chronic rhinosinusitis? Future Microbiol. 2017, 12, 1427-1442. [CrossRef]: http://doi.org/10.2217/fmb-2017-0073, [PubMed]: https://www.ncbi.nlm.nih.gov/pubmed/29027819

142.Zhang, G.; Zhao, Y.; Paramasivan, S.; Richter, K.; Morales, S.; Wormald, P.J.; Vreugde, S. Bacteriophage effectively kills multidrug resistant Staphylococcus aureus clinical isolates from chronic rhinosinusitis patients. International forum of allergy \& rhinology 2018, 8, 406-414.

[CrossRef]: http://doi.org/10.1002/alr.22046, [PubMed]:

https://www.ncbi.nlm.nih.gov/pubmed/29240296

143.Drilling, A.J.; Ooi, M.L.; Miljkovic, D.; James, C.; Speck, P.; Vreugde, S.; Clark, J.; Wormald, P.J. Long-term safety of topical bacteriophage application to the frontal sinus region. Front Cell Infect Microbiol 2017, 7, 49. [CrossRef]: http://doi.org/10.3389/fcimb.2017.00049, [PubMed]: https://www.ncbi.nlm.nih.gov/pubmed/28286740

144.Drilling, A.; Morales, S.; Jardeleza, C.; Vreugde, S.; Speck, P.; Wormald, P.J. Bacteriophage reduces biofilm of Staphylococcus aureus ex vivo isolates from chronic rhinosinusitis patients. American journal of rhinology \& allergy 2014, 28, 3-11. [CrossRef]: http://doi.org/10.2500/ajra.2014.28.4001, [PubMed]: http://www.ncbi.nlm.nih.gov/pubmed/24717868 
145.Town, A.E.; Frisbee, F.C. Bacteriophage in ophthalmology. Archives of Ophthalmology 1932, 8, 683-689. [CrossRef], [PubMed]:

146.Górski, A.; Targonska, M.; Borysowski, J.; Weber-Dabrowska, B. The potential of phage therapy in bacterial infections of the eye. Ophthalmologica 2009, 223, 162-165. [CrossRef]:

http://doi.org/10.1159/000193293, [PubMed]: http://www.karger.com/DOI/10.1159/000193293

147.Fadlallah, A.; Chelala, E.; Legeais, J.M. Corneal infection therapy with topical bacteriophage administration. The Open Ophthalmology Journal 2015, 9, 167-168. [CrossRef]:

http://doi.org/10.2174/1874364101509010167, [PubMed]:

http://www.ncbi.nlm.nih.gov/pubmed/26862360

148.Edlund, A.; Santiago-Rodriguez, T.M.; Boehm, T.K.; Pride, D.T. Bacteriophage and their potential roles in the human oral cavity. Journal of oral microbiology 2015, 7, 27423. [CrossRef]: http://doi.org/10.3402/jom.v7.27423, [PubMed]: http://www.ncbi.nlm.nih.gov/pubmed/25861745

149.Ly, M.; Abeles, S.R.; Boehm, T.K.; Robles-Sikisaka, R.; Naidu, M.; Santiago-Rodriguez, T.; Pride, D.T. Altered oral viral ecology in association with periodontal disease. mBio 2014, 5, e0113301114. [CrossRef]: http://doi.org/10.1128/mBio.01133-14, [PubMed]:

http://www.ncbi.nlm.nih.gov/pubmed/24846382

150.Shlezinger, M.; Houri-Haddad, Y.; Coppenhagen-Glazer, S.; Resch, G.; Que, Y.A.; Beyth, S.; Dorfman, E.; Hazan, R.; Beyth, N. Phage therapy: a new horizon in the antibacterial treatment of oral pathogens. Curr. Top. Med. Chem. 2017, 17, 1199-1211. [CrossRef]:

http://doi.org/10.2174/1568026616666160930145649, [PubMed]:

https://www.ncbi.nlm.nih.gov/pubmed/27770768

151.Khalifa, L.; Shlezinger, M.; Beyth, S.; Houri-Haddad, Y.; Coppenhagen-Glazer, S.; Beyth, N.; Hazan, R. Phage therapy against Enterococcus faecalis in dental root canals. Journal of oral microbiology 2016, 8, 32157. [CrossRef]: http://doi.org/10.3402/jom.v8.32157, [PubMed]: https://www.ncbi.nlm.nih.gov/pubmed/27640530

152.Nilsson, A.S. Phage therapy-constraints and possibilities. Ups J Med Sci 2014, 119, 192-198.

[CrossRef]: http://doi.org/10.3109/03009734.2014.902878, [PubMed]:

http://www.ncbi.nlm.nih.gov/pubmed/24678769

153.Singla, S.; Harjai, K.; Katare, O.P.; Chhibber, S. Encapsulation of bacteriophage in liposome accentuates its entry in to macrophage and shields it from neutralizing antibodies. PLOS ONE 2016, 11, e0153777. [CrossRef]: http://doi.org/10.1371/journal.pone.0153777, [PubMed]:

http://www.ncbi.nlm.nih.gov/pubmed/27115154

154.Matsuzaki, S.; Uchiyama, J.; Takemura-Uchiyama, I.; Ujihara, T.; Daibata, M. Isolation of bacteriophages for fastidious bacteria. In Bacteriophage therapy : from lab to clinical practice,

Humana Press ed.; Azeredo, J.; Sillankorva, S., Eds. Springer: New York, 2018; Chap. 1, pp. 3-10; 1940-6029 (Electronic);1064-3745 (Linking).

155.Wan, X.Q.; Li, H.M.; Bai, Y. Advances in phage therapy of Helicobacter pylori infection. World Chinese Journal of Digestology 2009, 17, 3623-3626. [CrossRef], [PubMed]:

156.Shan, J.; Teulières, L.; Clokie, M. Is there a place for bacteriophages in diagnosis and treatment of Lyme Disease?

157.Zakowska, D.; Bartoszcze, M.; Niemcewicz, M.; Bielawska-Drozd, A.; Knap, J.; Cieslik, P.; Chomiczewski, K.; Kocik, J. Bacillus anthracis infections - new possibilities of treatment. Annals of agricultural and environmental medicine : AAEM 2015, 22, 202-207. [CrossRef]:

http://doi.org/10.5604/12321966.1152065, [PubMed]:

http://www.ncbi.nlm.nih.gov/pubmed/26094508

158.Filippov, A.A.; Kirill, V.S.; Mikeljon, P.N. Bacteriophages against Biothreat Bacteria: Diagnostic, Environmental and Therapeutic Applications. Journal of Bioterrorism \& Biodefense 2013, S3: 010. [CrossRef]: http://doi.org/10.4172/2157-2526.S3-010, [PubMed]:

159. Houssaye, C. Evaluation in vitro d'une suspension de bactériophages anti-staphylococcique à usage thérapeutique. doctorat en Médecine, Pierre et Marie Curie, Paris, 2004.

160.Dublanchet, A.; Ketari, M. Otite externe à staphylocoque doré traitée par les bactériophages. 2007. 161.World Health Organization. (2015). Global action plan on antimicrobial resistance. World Health Organization. http://www.who.int/iris/handle/10665/193736 
162.Abedon, S.T. Phage therapy: various perspectives on how to improve the art. In Host-Pathogen Interactions: Methods and Protocols, Methods in Molecular Biology, (eds.), C.M.a.F.J.L.-B., Ed. 2018; Chap. 11, pp. 113-127; 1940-6029 (Electronic); 1064-3745 (Linking).

163.Abedon, S.T. Bacteriophage clinical use as antibacterial "Drugs": Utility and precedent. Microbiol Spectr 2017, 5. [CrossRef]: http://doi.org/10.1128/microbiolspec.BAD-0003-2016, [PubMed]: https://www.ncbi.nlm.nih.gov/pubmed/28840811

164.Ly-Chatain, M.H. The factors affecting effectiveness of treatment in phages therapy. Frontiers in Microbiology 2014, 5, 51-doi: 10.3389/fmicb.2014.00051. [CrossRef]:

http://doi.org/10.3389/fmicb.2014.00051, [PubMed]: http://www.ncbi.nlm.nih.gov/pubmed/24600439 165.Meaden, S.; Koskella, B. Exploring the risks of phage application in the environment. Frontiers in Microbiology 2013, 4, 358. [CrossRef]: http://doi.org/10.3389/fmicb.2013.00358, [PubMed]: http://www.frontiersin.org/Journal/Abstract.aspx?s=406\&name=evolutionary and genomic microbi ology\&ART DOI=10.3389/fmicb.2013.00358

166.Dufour, N.; Delattre, R.; Debarbieux, L. In vivo bacteriophage biodistribution. In Bacteriophage therapy : from lab to clinical practice, Azeredo, J.; Sillankorva, S., Eds. Humana Press: New York, 2018; Chap. 11, pp. 123-137; 1940-6029 (Electronic); 1064-3745 (Linking). 